\title{
Current state of populations of Rhodiola rosea L. (Crassulaceae) in East Kazakhstan
}

Serik A. Kubentayev' ${ }^{1}$ Moldir Zh. Zhumagul2*iD, Meruyert S. Kurmanbayeva², Daniar T. Alibekov', Jurii A. Kotukhov ${ }^{3}$ Gulnara T. Sitpayeva ${ }^{4}$, Saule K. Mukhtubayeva ${ }^{1}$ and Klara S. Izbastina ${ }^{1}$

\begin{abstract}
Background: Based on world experience, first, a modern assessment of the flora is needed to develop strategies for the conservation of ecosystems of rare and endangered plant species. A regional and global biodiversity strategy should focus on assessing the current state of bioresources. To preserve the biodiversity of the species and its habitat, we evaluated botanical features, ontogenetic phases, the ecological and phytocenotic structure of the rare and endangered of Rhodiola rosea L. (golden rose root) populations from the highlands of Eastern Kazakhstan.

Results: $R$. rosea in the study region lives on damp mossy rocks, rocky slopes, overgrown moraines and along the banks of mountain rivers in the upper limit of cedar-larch forests, subalpine and alpine belts, in the altitude limit of 1700-2400 m. In the studied region, R. rosea begins to vegetate in May-June, blooms in June-July, the fruits ripen in August. The species is encountered in the high mountain ranges of the Kazakh Altai and Saur-Tarabagatai. Unfavorable habitat conditions for the species are overgrown by sedge-grass and birch-moss communities. The most common species at sites with R. rosea are: Schulzia crinita, Achillea ledebourii, Doronicum altaicum, Macropodium nivale, Hylotelephium telephium, Rhodiola algida, Carex capillaris, C. aterrima. Ontogenetic study revealed that all age-related phases were present, with the exception of the senile states. Individual life expectancy shown to be 50-55 years. The analysis of the species composition in the communities with $R$. rosea showed that the leading families in terms of the number of accompanying species are Poaceae, Ranunculaceae, Asteraceae, Rosaceae and Caryophyllaceae, Apiaceae, Fabaceae; while the most dominant genera are: Carex, Aconitum, Dracocephalum, Festuca, Pedicularis, Poa, Salix; the ecological groups are dominated by psychrophytes, mesophytes mesopsychrophytes; the Asian, Eurasian, and Holarctic groups are the most represented groups. Dominant life forms according to Serebyakov were rod-rooted, brush-rooted, shortrooted and long-rooted grasses, while based on Raunkiaer's groups the overwhelming majority consisted of Hemincryptophytes (74\%).
\end{abstract}

Conclusions: The R. rosea populations of Kazakhstan represent an important gene stock of the species. Our study provides new insights into the species' biology thus contributes to the conservation of biodiversity on a wide spatial scale.

Keywords: Ontogenesis, Kazakh Altai, Asia, Chorological analysis, Life forms, Morphological and quantitative indicators, Conservation, Sedum roseum

\footnotetext{
*Correspondence: mzhakypzhan@mail.ru

${ }^{2}$ Al-Farabi Kazakh National University, Almaty, Kazakhstan

Full list of author information is available at the end of the article

This article belongs to the Topical Collection: Ecology.
}

\section{Background}

The study of the ecological and botanical characteristics of natural populations of rare and vulnerable plants remains a priority in the strategy of biodiversity conservation, especially if they are Wild Relatives of crops (Perrino and Wagensommer 2021). Currently, many valuable medicinal plants are subjected to spontaneous gathering, 
as a result of which the number and areas of natural habitats are decreasing, the natural balance in communities is disrupted, which leads to population degradation (Cunningham et al. 2020).

This concerns $R$. rosea, the demand for which has grown significantly throughout the world in recent years, which threatens the extinction of natural populations on a global scale. The global demand for $R$. rosea raw material will continue to grow (Bernard 2016), which could lead to catastrophic consequences. The main drivers of the increased demand for $R$. rosea raw materials are the expansion of the range of drugs, dietary supplements, and cosmetics containing $R$. rosea (Brinckmann et al. 2020). A highly important priority is to preserve the natural environment in which $R$. rosea grows and it is a high priority is to evaluating the type and flock size of the grazing in order to preserve their natural habitat, using sustainable criteria (Perrino et al. 2021; Buse et al. 2015). Nowadays $R$. rosea is classified as rare and endangered species, in many regions-as a protected plant. The growing demand increases the load on the natural populations of the species. As a result, it has become a threat object in many Eurasian countries, including the Czech Republic (Grulich 2012), Slovakia (Ferakova et al. 2001), Bosnia and Herzegovina (Platikanov and Evstatieva 2008), Bulgaria (Tasheva and Kosturkova 2012), Germany (Metzing et al. 2018), Austria (Niklfeld and Schratt-Ehrendorfer 1999), the Russian Federation (Trutnev et al. 2008), Mongolia (Urgamal 2018), China (Qin 2017).

One reliable way to preserve this species is to introduce it into cultivated culture (Karpukhin and Abramchuk 2020). The scientists suggest that in situ protection is insufficient to preserve the gene pool of the $R$. rosea population. It seems appropriate to create ex situ populations and return them to nature (Hou and Lou 2011). It is successfully cultivated in botanical gardens and in research institutes of plant growing in Russia (St. Petersburg, Gorno-Altaisk, Novosibirsk, Irkutsk, etc.) (Moryakina et al. 2008) as well as in European countries: Bulgaria (Platikanov and Evstatieva 2008), the United Kingdom (Peschel et al. 2018), Poland (Buchwald et al. 2015), Italy (Fusani 2019).The regenerative capacity of wild plants is limited due to the very low seed germination rate (5-35\%) and the coefficient of vegetative reproduction (Platikanov and Evstatieva 2008). In view of the above, the widespread use of natural specimens in many countries has led to the disappearance of the species, which has provoked the adoption of a number of conservation measures: cultivation in appropriate conditions (Matthys et al. 2007). In many countries, sustainable ecological use of natural resources, the conservation and the preservation of natural areas as a special environmental activity are regulated (Yaneva et al. 2020).
Despite the great interest in the $R$. rosea and extensive research in the field of phytochemistry, plant bio-technology remained less researched and widely used (Li et al. 2019; Olsson et al. 2009). The stages of morphogenesis of the species and the maximum age of wild populations of $R$. rosea are also poorly studied (Brinckmann et al. 2021). The studies of many Russian scientists are devoted to the study of ecological and botanical proper-ties, distribution, ontogeny of populations (Sofronov et al. 2016; Valuiskih et al. 2017; Panossian et al. 2010; Yakubov et al. 2019; Shadrin et al. 2020). A relatively fewer population ecological studies of $R$. rosea were performed in Europe and North America (Olfelt et al. 2014; Aiello et al. 2013), however, the research on genetic diversity and phylogeography of populations are well represented (György et al. 2012; György et al. 2013; György et al. 2014; Soni et al. 2010; Kozyrenko et al. 2018).

Rhodiola rosea L. (Crassulaceae DC) has a wide circumpolar distribution in the northern hemisphere from the low-Arctic to high-temperature regions of Asia, Europe, and North America (Cuerrier 2014; Brinckmann et al. 2021). It is a rare species included in the Red Book of Kazakhstan (2014) with III class status and is regarded as a threatened species. According to the data of International Union for the Conservation of Nature Resources (IUCN), the rarity category is Least concern (LC) (Chadburn 2020). It is guarded in Katon-Karagai State National Natural Park, Markakol and Eastern Altai protected area in the researched region. It grows in alpine and subalpine vegetation belts, stony tundra's, on the rocks and rocky hills, on placers and moist soils along river banks. In Kazakhstan, it has been documented in three floristic regions: Altai, Tarbagatai, Dzhungarskiy Alatau (Vasilyeva 1961). Distribution area is in the Southern Siberian mountains, in the Ural, in transpolar regions of Yakutia, in the highland areas of Eastern Siberia and Far East, on the coasts of White and Barancevo seas, in Mongolia, China, North America and in Asia Minor (Borisova 1939; Vasilyeva 1961; Ivanova 1979; Peshkova 1994).

Therefore, purpose of the work is to study distribution and density of $R$. rosea populations in East Kazakhstan, floristic and habitat characteristics, including variation in ontogenetic states of the individuals.

\section{Materials and methods}

The Kazakhstan part of Altai is a system of ridges in the southern and the southwestern part of Altai, as a mountainous country that stretches from south to north and from west to east for almost $400 \mathrm{~km}$. It is a part of the southwestern periphery of the Altai-Sayan mountain system and with its inherent structure of landscape and high-altitude zones. According to the physical and geographical conditions, the territory of the Kazakhstan 
Altai is subdivided into three subdistricts which are Southwestern Altai, Southern Altai, Kalbinsk Highlands (Yegorina et al. 2003).

The research was carried out between 2015 and 2020 in Southern Altai (Narym, Sarymsakty, Southern Altai Tarbagatai, Kurchym ridges) and Western Altai (Ivanov, Ubi, Ulbi, Koksim Linei, Western Listvyaga ridges) of Kazakhstan part. The investigated region administratively belongs to the East Kazakhstan region. The geographic zoning and names of mountain ridges are specified according to the Physical Map of Kazakhstan. To identify the phytocenotic features of $R$. rosea populations, the traditional methods of field geobotanical studies were perfumed using the ecological-physiognomic approach. The ecological and physiognomic types combine plant communities with dominants belonging to one ecobiomorph and ecologically similar groups of species (Bykov 1970).

The description of the populations was carried out using special description forms. In each population, 15 study sites were laid, the area of the site was: $10 \times 10 \mathrm{~m}$ $\left(100 \mathrm{~m}^{2}\right)$. A total of 150 sites were taken into account. The GPS device recorded the marginal points of the community boundaries to identify the area. First, general information was written in the form: description number, geographical location, date, coordinates, height, site size, photo number, then the following main sections are reflected in the form: The name of the vegetation type based on dominant species; the floral composition of the community with an indication of occurrence of species. To do this, we selected a section in the redevelopment of a homogeneous contour. The GPS device determined the coordinates and the absolute height.

To calculate the frequency of species in the floristic composition of $R$. rosea communities, all plant species were accounted for in each surveyed accounting site, the obtained values were grouped into five occurrence classes: I-0-20\%, II-21-40\%, III-41-60\%, IV-61-80\%, $\mathrm{V}-81-100 \%$.

The rarity category and status of the species are indicated in accordance with the Kazakhstan Red Data Book (Kazakhstan Red Data Book 2014) and The IUCN Red List of Species (IUCN 2020). Uranov (1969) method was applied for the purposes of researching the life cycles. The methodological guidelines developed by Golubev and Molchanov (1978) were used as a basis for studying ecological, biological properties of the species in the reallife field conditions.

The spectra analysis of geographic elements of floras of various ranks, including floras of plant communities in the scope of specified classification units (composition of the floras) is one of the main tools of comparative floristical studies. Composition of the flora is a set of plant species which form communities of any rank and any type of vegetation. From this point of view, the composition of the flora represents the unification of historically and coenotically homogeneous groups of species within the syntaxon, which makes them the most important indicator of the vegetation cover from the level of a particular phytocenosis to altitudinal-belt units. The life forms of plants of the floristic composition of $R$. rosea communities are given according to the classifications of Serebryakov (1962) and Raunkiaer (1934). Species composition in $R$. rosea communities by ecological groups and area of species are given according to the classification of Kuminova (1960).

Plant names are listed according according to Plants of the World Online (POWO 2021). The analysis of species' floral composition in the surroundings of $R$. rosea was carried out in comparison with the Alpine flora of Altai (AFA) (Revushkin 1988).

The studies were conducted according to the scheme proposed by Rabotnov (1964) and Smirnova (1976). The following classification of the age groups were used in the description: plantlets (p), juvenile (j), immature (im), virginile (v), young generative (g1), mature generative (g2), old generative (g3), ageing individuals (a.i.). " Distribution map of $R$. rosea in East Kazakhstan" was obtained by ArcMap.

According to the number of fibers remaining annually after the death of the shoots on the $R$. rosea rhizome, it is possible to judge the age of plants. In any cenosis, as a rule, all species are represented by numerous individuals of various ages, from seedlings to old plants. We studied all individuals of the species in different populations and established the course of accumulation of fibers with age, and based on this we calculated the age of individuals. Undoubtedly, the determination of the age of individuals by this method may be inaccurate, since some of them are characterized by a very slow course of development, while others, on the contrary, develop very quickly. However, the accuracy of age determination increases with an increase in the number of studied individuals. We determined the age of 100 individuals from different populations.

Based on the long-term herbarium collections of the authors of this work stored in Altai Botanical Garden (further referred to as 'Alt.') and Astana Botanical Garden (NUR), as well as a result of the revision of the herbarium materials of the Moscow State University (MW) (Seregin 2020) and the herbarium of the Institute of Botany and Phytointroduction (AA), the distribution of $R$. rosea in Eastern Kazakhstan was revealed. In addition, the following literature were taken into account: Perrino et al. 2021; Artemov 2020; Kotuhov 2005; Isayev 1993; Zibzeyev and Nedovesova 2015; 
Kubentayev et al. 2018, Kubentayev et al. 2019. The distribution map is shown in Fig. 1.

The correlation analysis was calculated using the Rstudio software (Rstudio Team 2015). Statistics of morphometric parameters were performed using the program Statistica 10 (StatSoft STATISTICA 10 2011).

\section{Results}

\section{Distribution of $R$. rosea in East Kazakhstan}

$R$. rosea is distributed on the ridges of the Kazakhstan Altai and Tarbagatai in the East Kazakhstan region. The species is found in the following administrative districts: Katon-Karagaysky, Kurchumsky, Riddersky, Glubokovsky and Urdzharsky districts. The examined herbarium samples are given below.

Specimens examined: WESTERN ALTAI: was revealed: Ivanovski ridge: vicinity of Ridder mountain, Khorizovka river narrow, 29.VI.1936, Rubam \& Mikhailova (AA); near the small area, between blocks of moraine debris, 15.VI.2015, Kubentayev (NUR); top of Poperechka river, along the river bank, 03.VII.2012. Kotukhov (Alt.); «Prohodnoj belok», along the damp rocky places, 10.VI.2016,
Kubentayev (NUR); vicinity of Rodonovoi river, along the damp rocky places, 10.VI.2015, Kotukhov (Alt.); Ulbi ridge (northern faces of Kreslova mountain, Ridder region, 26.VII.1937, Kuznecov (AA, MW); Lineiski ridge: valley of Chernaya Uba river, south- western slope on the altitude of 1830 m., 03.VII.1998, Kotukhov (Alt.); Koksi ridge: in Latuniha river-valley, 27.VI.2003, Kotukhov (Alt.); in Chernaya Uba river-valley, 03.VI.2003, Kotukhov (Alt.); Ulbi ridge: Bolshoi Turgusun rivervalley, 15.VI.2004, Kotukhov (Alt.); top of Tatarka river, 15.VII.2004, Kotukhov (Alt.); Ubi ridge: Belaya Uba river-valley, 12.VI.2006, Kotukhov (Alt.). IN SOUTHERN ALTAI: Chindagatui mountains: Southern Alai ridge, moist meadow in the lower part of the slope, $1800 \mathrm{~m}$., 27.VII.1986, Ivaschenko \& Utebekov (AA); Narym ridge: Koksar mountain, 7.VII.1973, Mikhailov \& Stepanova (AA); Southern Altai-Tarbagatai ridge: Burkhat pass, northern slope at the top of the forest, 14.VII.1973, Isayev (AA); left bank of Karakaba river, northern slope, 2100 m., 28. VI.1988, Ivaschenko (AA); vicinity of Chernovoye village, in the upper part of the forest, 15.VI.2016, Kubentayev (Alt.); in the vicinity of the bridge across

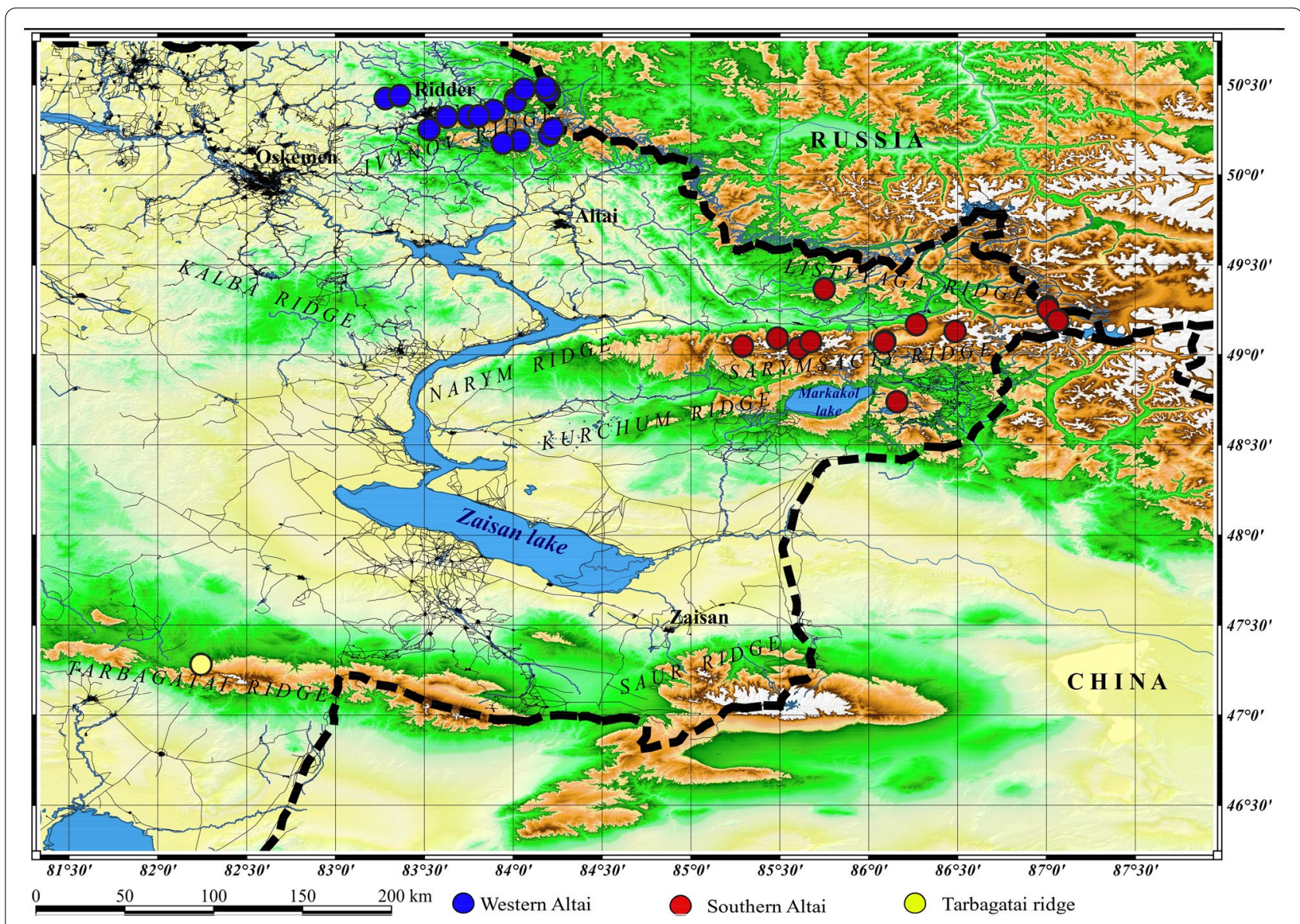

Fig. 1 Scheme map of the distribution of the R. rosea in East Kazakhstan (Scheme map was obtained by ArcMap) 
Karakaba river along the Austria road, damp rocky places, 18.VI.2016, Kubentayev (NUR); to the southerneast of Enbek village, at the top of a ridge in the alpine belt, 01.VI.2017, Kotukhov (Alt.); Sarymsakty ridge: Kumshybai, by the stream along the path to the waterfall, damp meadows, 22. VI.1986, Ivaschenko (AA); at the top of Solonechnaya river, 22.VIII.2010. Kubentayev \& Zhumagul (NUR); in the vicinity of Topkain river, alpine meadows, 10.VIII.2020. Kubentayev (NUR); Western Listvyaga ridge: at the foot of Schebniuha hill, valley of mountain river, 10.VII.2019, Kubentayev (NUR); Repnoie river head, Kubentayev \& Zhumagul, 22.VII.2019; vicinity of Aksharbak village, Katon-Karagai region, Verhkatun riverhead, 22.VII.2020. Kubentayev (Alt.).

\section{Ecological-biological and phytocenotic structure of $R$. rosea populations}

The study of $R$. rosea populations was carried out at 4 geographic sites: Ivanov ridge (4 population); (2) Sarymsakty ridge (2 Population); (3) Southern-Altai Tarbagatai ridge (2 Population); (4) Western Listvyaga ridge (2 Population) belonging to the territory of Kazakhstan Altai
(22. Altai), according to the floristic zoning of Kazakhstan (Kazakhstan Flora 1957). The species populates wet moss-covered rocks, rocky hills, near snowfields, overgrowing morains, among moss along the river banks, in the upper limit of mossy cedar-larch forests (Fig. 2).

1. Population (Macropodium nivale-A ngelica archangelica $-R$. rosea ) is timed to the western slopes of shallow ravines of shallowed river beds (Fig. 3). The population was studied at Burkhat pass, Sarymsakty ridge, $\left(49^{\circ} 07^{\prime} 49.9^{\prime \prime} \mathrm{N}, 86^{\circ} 02^{\prime} 19.8^{\prime \prime} \mathrm{E}\right)$ in the altitude of $1950-2050 \mathrm{~m}$. Projective cover (PC) is $55 \%$. Standing grass is formed diffusively, along the rock cracks, between the debris of blocks and in degradations where the fertile soil layer accumulates. Recorded accompanying species: Coptidium lapponicum, Aquilegia glandulosa, Sanguisorba alpina, Rumex acetosa, Bistorta elliptica, Trollius altaicus, Geranium albiflorum and etc. in the community. The population of $R$. rosea as a rule, is represented by all age classes with predominance of generative adult specimens. The state of this popu-

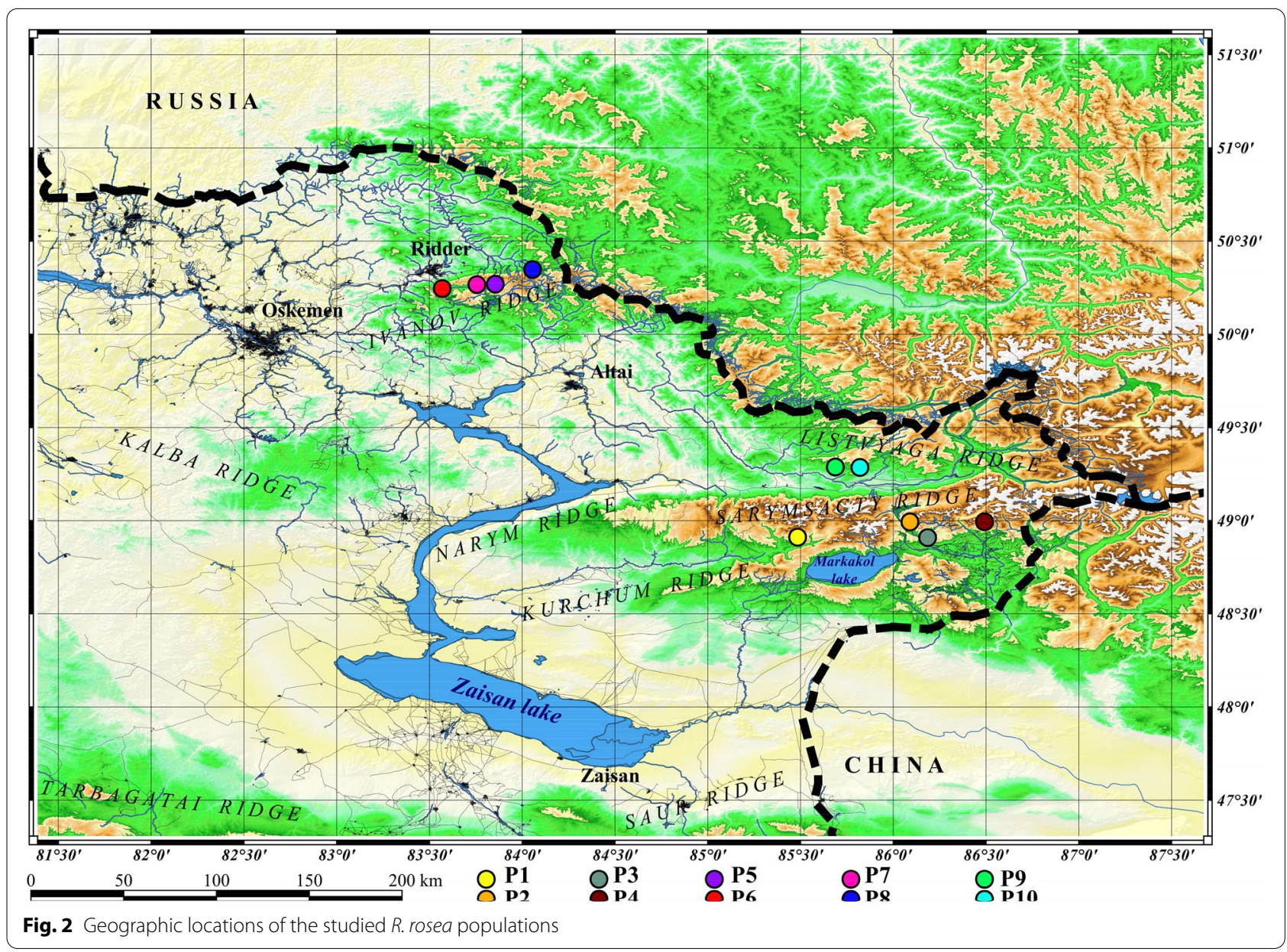




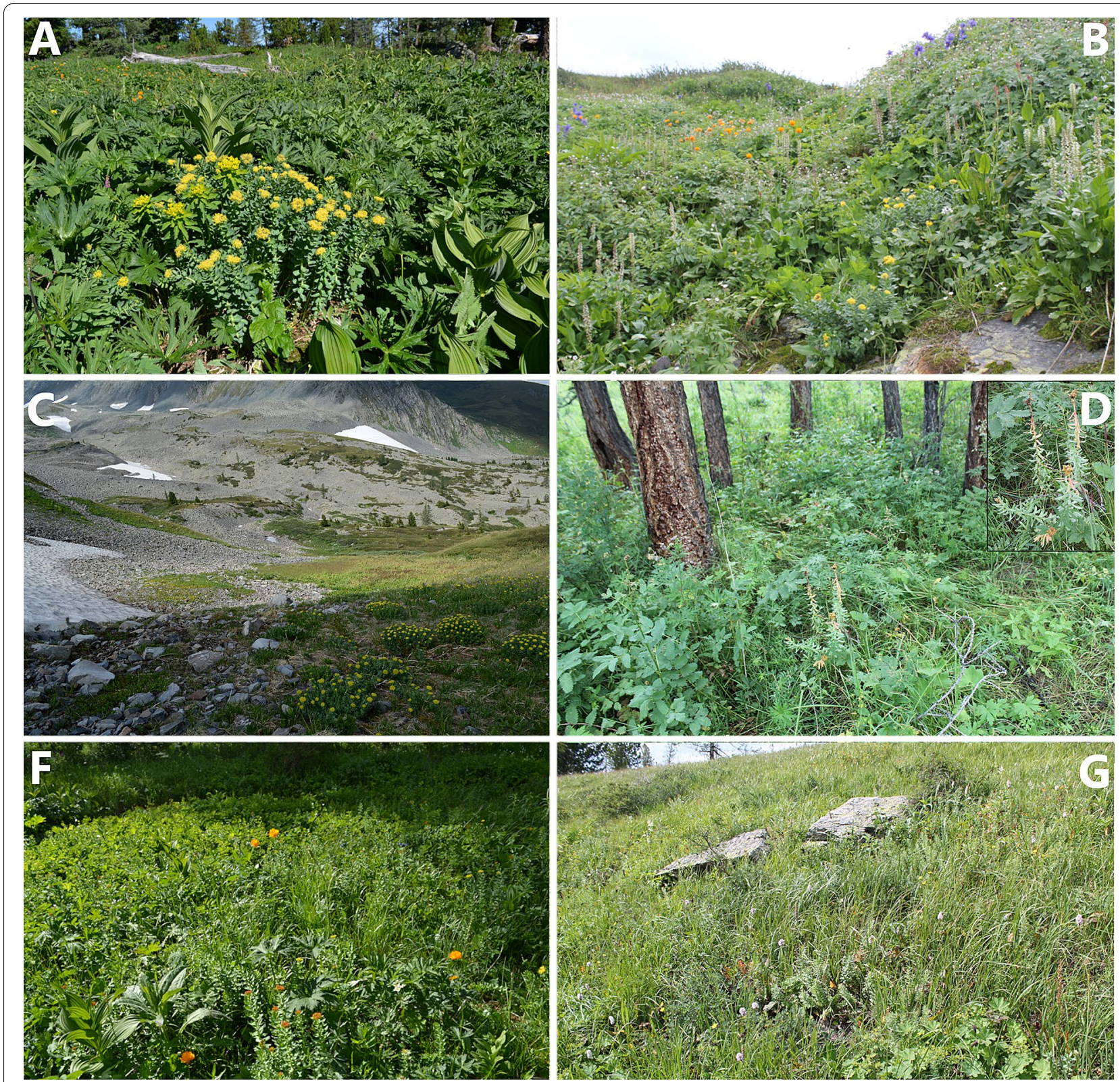

Fig. 3 Populations of $R$. rosea in different ecological conditions ( $\mathbf{A}$ in damp alpine meadows; $\mathbf{B}$ in shallow shallow riverbeds; $\mathbf{C}$ on weakly overgrown moraines near glaciers; $\mathbf{D}$ in cut cedar-larch forests; $\mathbf{F}$ in motley grass alpine meadows; $\mathbf{G}$ in heavily overgrown herb-grass areas (degrading populations)

lation of $R$. rosea is characterized as stable, capable of self-renewal.

2. Population (Carex stenocarpa + C. orbicularis $+R$. rosea +Dracocephalum grandiflorum) occurs in well overgrown steep moraine slopes, Sarymsakty ridge, Solonechny river $\left(49^{\circ} 05^{\prime} 34.7^{\prime \prime} \mathrm{N}\right.$, $\left.85^{\circ} 29^{\prime} 10.3^{\prime \prime E}\right)$. Moraine hillocks are located on the steep northwestern slopes of the ridges in the altitude of 1900-2100 $\mathrm{m}$ above the sea level with closely located snowfields. PC is $80-90 \%$. Typical species for these communities are Festuca kryloviana, Allium schoenoprasum, Hedysarum neglectum, Anemonastrum narcissiflorum, Thalictrum alpinum, Papaver nudicaule, Neogaya simplex, Gentiana grandiflora, Pedicularis oederi, P. amoena, P. violascens, Oxytropis alpine, rare enough Gentiana algida, Papaver nudicaule, Festuca altaica. Betula rotundifolia should be noted 
among the shrubs, which forms separate small patches. Favorable water and temperature conditions, high humus content in the soil determine the lush development of vegetation, which negatively affects the populations of $R$. rosea due to its low competitiveness.

3. Population (Alchemilla gottsteiniana-Polygonum ellipticum $+R$. rosea) is timed to smooth slopes of alpine meadows on the meadow soils (Fig. 3), Southern Altai Tarbagatai, Karakaby depression, Kara-Kaba river-valley $\left(49^{\circ} 04^{\prime} 06.8^{\prime \prime} \mathrm{N}, 86^{\circ} 05^{\prime} 14.8^{\prime \prime} \mathrm{E}\right)$. Total PC is $85 \%$. The shrub layer is poorly expressed, Lonicera altaica, Potentilla glabra is rare Spiraea media shrubs are only noted. Koenigia alpina, Phleum alpinum, Valeriana dubia, Rumex acetosa Galium boreale, Iris ruthenica, Dracocephalum grandiflorum, Aster alpinus, Papaver nudicaule, Vicia cracca, Sedum hybridum, Pedicularis achilleifolia, Pachypleurum alpinum, Oxytropis alpina, Gentiana algida, Crepis chrysantha are frequently often encountered in the phytocoenosis. $R$. rosea population in this type undergo degradation. Gradually expanding, meadow vegetation displaces $R$. rosea from familiar habitats. Ontogenesis is dominated by generative and senile individuals, reproduction by seeds is absent.

4. Population (R. rosea + Anemonastrum narcissiflorum - Cazex aterrima - Thermopsis alpina - Viola biflora) occupy excessively cold, moderately humid rocky peaks and southwestern slopes of weakly closed pressure moraine ridges in the altitude limit of 2000-2300 m. above sea level, Southern Altai Tarbagatai ridge $\left(49^{\circ} 10^{\prime} 04.4^{\prime \prime} \mathrm{N}, 86^{\circ} 16^{\prime} 07.3^{\prime \prime}\right.$ E). PC is $30 \%$. The vegetation cover is less developed and relatively poor in terms of species. The most common herbaceous plants are, Carex capillaris C. orbicularis, C. rupestris, Schulzia crinita, Micranthes punctata, Papaver croceum, Salix rectijulis, Dryas oxydontha, Silene graminifolia, Koenigia alpina, Minuartia verna, Patrinia sibirica is relatively common among shrubs. This $R$. rosea population is represented mainly by aging generative and very old individuals. Analysis behind the developmental state of $R$. rosea in the upper limit of its distribution suggest considering grounds to consider these habitats as extreme.

5. Population (Hedysarum neglectum + Carex orbicularis + C. aterrima - R. rosea) occurs in weakly covered moraine ridges (Fig. 3), Ivanov ridge, upper parts of Big Poperechka river $\left(50^{\circ} 19^{\prime} 13.5^{\prime \prime} \mathrm{N}\right.$, $83^{\circ} 45^{\prime} 11.0^{\prime \prime E}$ ). Plants are usually along the northwestern microslopes, on the altitude of 2000-2300. PC is $70 \%$. Species observed here were Rhodiola algida, Dryas oxyodonta, Bergenia crassifolia, Hedysarum neglectum, Pedicularis achilleifolia, Neogaya simplex, Oxytropis alpina, Pedicularis amoena, P. oederi, in the community Hedysarum theinum, Saussurea alpina, Schulzia crinita, Luzula spicata occurs comparatively rare. Open areas are densely covered by Polytrichum juniperinum, $P$. alpinum mosses and species from the genus Bryo. Patches of lichens from the genus Cladonia are commonly encountered. $R$. rosea in the coating occupies no more than $5-6 \%$ of the total surface.

6. Population (Deschampsia caespitosa + Senecio pratensis $+R$. rosea) observed on moderately humid stony-mobile fine-gravel slopes of moraine ridges, Ivanov ridge, passing snow-covered mountain peak $\left(50^{\circ} 15^{\prime} 10.3^{\prime \prime} \mathrm{N}, 83^{\circ} 31^{\prime} 31.8^{\prime \prime} \mathrm{E}\right)$. It is encountered on the altitude of $1800-1900 \mathrm{~m}$ above sea level. PC is not more than $40 \%$. In this kind of conditions $R$. rosea grows far from drains, constantly face the lack of moisture. The vegetation cover is dense, accompanying species are: Carex pediformis var. macroura, C. capillaries, Festuca borissii, Helictotrichon altaicum, Lagotis globosa, Callianthemum alatavicum, Saussurea alpina, Dracocephalum grandiflorum here in the community. Dryas oxyodonta, Thalictrum alpinum, Gentiana algida, Eritrichium villosum, Allium schoenoprasum, Pachypleurum alpinum, Crepis chrysantha are encountered very rarely. Plants do not form dense tangled vegetation. They are encountered in separate groups or as single individuals. Betula rotundifolia, Cotoneaster uniflorus are rare among the shrubs, and Juniperus sibirica is individually encountered.

7. Population ( $R$. rosea -Trisetum altaicum-Deschampsia cespitosa) occupy cold waterlogged coastal lake habitats, Ivanov ridge, near Maloye lake $\left(50^{\circ} 18^{\prime} 36.9^{\prime \prime} \mathrm{N}, 83^{\circ} 44^{\prime} 44.7^{\prime \prime} \mathrm{E}\right)$, on the altitude of $2000-2100 \mathrm{~m}$ above sea level. Population lives at the northeastern shores of a permanent dammed lake in the close proximity of the water. PC is $15-25 \%$. Tangles of $R$. rosea occupy a narrow coastal strip from the very edge of the water that is only $1.5-2 \mathrm{~m}$ wide. The vegetation cover is represented by separate plants or small groups of the communities, where Carex aterrima, Deschampsia cespitosa, Festuca borissii, Trisetum altaicum, Phleum alpinum, Swertia obtuse, Primula nivalis, Rhodiola algida, Sanguisorba alpina, Caltha palustris, Bistorta vivipara, Allium schoenoprasum, Gentiana algida are often encountered. Salix lanata and $S$. rectijulis are relatively rare. Among the herb layer, $R$. rosea is encountered relatively abundantly, 
the habitat conditions for the species can be considered close to optimal.

8. Population (Salix lanata-Betula rotundifolia$R$. rosea ) occupies moderately humid bushy tundra habitats, in Ivanov ridge $\left(50^{\circ} 19^{\prime} 36.4^{\prime \prime} \mathrm{N}\right.$, $\left.83^{\circ} 48^{\prime} 17.8^{\prime \prime} \mathrm{E}\right)$. The communities with the participation of $R$. rosea are timed to the northwestern steep slopes on the altitude limit of $2100-2200 \mathrm{~m}$ above sea level. PC is $50-60 \%$. The herb layer is less abundant, Carex aterrima, Trollius altaicus, Pedicularis oederi, Thalictrum alpinum, Macropodium nivale, Geranium albiflorum, Gagea serotina are encountered. Betula rotundifolia tangles reach a height of $35-40 \mathrm{~m}$, rarely $50 \mathrm{~m}$. In this population, $R$. rosea grows in extreme habitat conditions, the population is aging, supported by inefficient vegetative reproduction. Gradually expanding, tangles of birches crowd them out from their habitats.

9. Population (R. rosea + Achillea ledebourii- Veratrum lobelianum - Sanguisorba alpine) occupies coastal and excessive wet meadows, constant verges of the streams, cedar-larch (Pinus sibirica, Larix sibirica) wood meadows on the altitude of 1700-1900 m (Fig. 3), Western Listvyaga, upper part of Repnaya river $\left(49^{\circ} 21^{\prime} 06.0^{\prime \prime} \mathrm{N}, 85^{\circ} 41^{\prime} 54.8^{\prime \prime} \mathrm{E}\right)$. Excessive moisture and light shading throughout the growing season create unfavorable conditions for the development of $R$. rosea. The vegetation cover is relatively rich in species diversity, PC is $65-80 \%$. Accompanying species are: Alchemilla altaica, Primula nivalis, Carex curaica, C. aterrima are often encountered in the community, while Carex orbicularis, Cerastium davuricum, Bistorta vivipara, Trollius altaicus, Deschampsia cespitosa, Allium schoenoprasum, Myosotis scorpioides, Delphinium elatum, Caltha palustris are rarely encountered. $R$. rosea is timed to areas in the form of narrow ribbons of $1.5-2 \mathrm{~m}$ width along the coasts. There are no shrubs. In rare cases, Lonicera altaica was noted along the coastline. $R$. rosea forms small clumps on areas bare from grass. In this habitat type generative individuals are dominating.

10. Population ( $R$. rosea -Dichodon cerastoides-Allium schoenoprasum) occupy the shores of mountains streams, wells, drains which are of temporary natural due the process of snow melting patches of which the drying begins from the mid July, locations is Western Listvyaga ridge, in the vicinity of Schebnuiha mountain $\left(49^{\circ} 21^{\prime} 54.0^{\prime \prime} \mathrm{N}\right.$, $85^{\circ} 44^{\prime} 58.9^{\prime \prime} \mathrm{E}$ ), on the altitude limit of $2000-2200 \mathrm{~m}$. $R$. rosea plants grow on the boulders covered by the thick moss cover. The vegetation cover in the phytocenosis is poorly expressed. PC is $30-40 \%$. The following species are encountered in the community: Primula nivalis, Carex orbicularis, C. aterrima, Bistorta vivipara, Pedicularis oederi, Deschampsia cespitosa, Micranthes punctata, Macropodium nivale, Sanguisorba alpina, Lagotis globosa, Gentiana algida. Populations of $R$. rosea are of normal type, young, habitat conditions can be considered optimal.

Table 1 demonstrates the morphometric parameters of $R$. rosea in the surveyed populations of Kazakhstan Altai. According to the data obtained, the highest number of individuals per $1 \mathrm{~m}^{2}$ was observed in P10 (0.75), P7 (0.68) and P1 (0.56), a relatively low number per unit area was noted in P8 (0.18), P 6 (0.21) and in P3 (0.23). $R$. rosea populations with a high number of individuals per unit area, are composed of mostly undersized, multi-shoot shrubs having large flowers. In the population with a low abundance of Rhodiola specimens per unit area, tall individuals are observed, with loose, low-shoot bushes and relatively small flowers. $R$. rosea populations growing in habitats with a high number of accompanying species are multi-stemmed and have large flowers. Populations with a low number of individuals, are characterized by tall, crumbly, low-running bushes and relatively small inflorescences. This pattern is explained by the habitat conditions. As a rule in the forest belt and in tall grass communities the specimens of $R$. rosea are relatively tall $(45-50 \mathrm{~cm})$, have crumbly low-running bushes (6-10 pcs) and small inflorescences $(3-4.5 \mathrm{~cm})$. In open, poorly populated areas, and along the valleys of mountain streams, individuals are significantly undersized $(20-25 \mathrm{~cm})$, but have a multistem structure (30-50 pcs) and develop large flowers $(5.2-6 \mathrm{~cm})$ (Fig. 4).

\section{Phenology of $R$. rosea in East Kazakhstan}

$R$. rosea begins to vegetate under snow cover starting from mid-May to mid-June in the studied area and when the snow melts, it begins to grow rapidly. Flowering period lasts from mid-June to late July. The fruits ripen from August to September. It should be noted that the seasonal rhythm of the species' development depends on the height of the location of the population. The species begins to grow from mid-May in the upper limit of the green belt at an altitude of 1700-1900 m. $R$. rosea grows in the second half of June in the alpine belt at an altitude of $2200-2400 \mathrm{~m}$. On average, the growing season lasts 4 months. 
Table 1 Quantitative and morphological indicators of R. rosea specimens from the study plots P1-P10

\begin{tabular}{|c|c|c|c|c|c|}
\hline \multicolumn{2}{|c|}{$\begin{array}{l}\text { Quantative and } \\
\text { morphological Values }\end{array}$} & \multirow{2}{*}{$\begin{array}{l}\begin{array}{l}\text { Number of adult } \\
\text { specimens per } 1 \mathrm{~m} 2\end{array} \\
0.56\end{array}$} & \multirow{2}{*}{$\begin{array}{l}\text { Height of generative species at the } \\
\text { time of blooming }(\mathbf{c m})\end{array}$} & \multirow{2}{*}{$\begin{array}{l}\text { The number of shoots per a } \\
\text { specimen (pcs) } \\
21.41\end{array}$} & \multirow{2}{*}{$\begin{array}{l}\text { Inflorescence } \\
\text { Diameter (cm) }\end{array}$} \\
\hline P1 & M & & & & \\
\hline & SD & 0.03 & 1.62 & 2.01 & 0.31 \\
\hline \multirow[t]{2}{*}{ P2 } & M & 0.32 & 48.33 & 15.22 & 4.20 \\
\hline & SD & 0.01 & 1.28 & 1.61 & 0.26 \\
\hline \multirow[t]{2}{*}{ P3 } & M & 0.23 & 35.52 & 6.91 & 4.35 \\
\hline & SD & 0.01 & 2.12 & 0.65 & 0.16 \\
\hline \multirow[t]{2}{*}{ P4 } & M & 0.28 & 26.66 & 20.32 & 3.63 \\
\hline & SD & 0.01 & 2.91 & 1.71 & 0.18 \\
\hline \multirow[t]{2}{*}{ P5 } & M & 0.42 & 47.22 & 28.31 & 5.39 \\
\hline & SD & 0.04 & 1.81 & 2.16 & 0.27 \\
\hline \multirow[t]{2}{*}{ P6 } & M & 0.21 & 38.30 & 12.27 & 4.23 \\
\hline & SD & 0.01 & 1.21 & 1.63 & 0.15 \\
\hline \multirow[t]{2}{*}{ P7 } & $M$ & 0.68 & 31.19 & 36.55 & 5.46 \\
\hline & $\mathrm{SD}$ & 0.02 & 1.72 & 1.11 & 0.31 \\
\hline \multirow[t]{2}{*}{ P8 } & $M$ & 0.18 & 49.29 & 8.12 & 3.81 \\
\hline & SD & 0.01 & 2.33 & 0.69 & 0.25 \\
\hline \multirow[t]{2}{*}{ P9 } & $M$ & 0.33 & 45.61 & 6.06 & 3.22 \\
\hline & SD & 0.03 & 2.72 & 0.31 & 0.13 \\
\hline \multirow[t]{2}{*}{ P10 } & $M$ & 0.75 & 32.30 & 37.33 & 4.81 \\
\hline & SD & 0.03 & 1.44 & 2.82 & 0.33 \\
\hline
\end{tabular}

\section{Ontogenetic state $R$. rosea}

The ontogenetic state of $R$. rosea was studied on Ivanov ridge, in the upper parts of Big Poperechka river $\left(50^{\circ} 19^{\prime} 13.5^{\prime \prime} \mathrm{N}, 83^{\circ} 45^{\prime} 11.0^{\prime \prime} \mathrm{E}\right)$.

The species in the surveyed area reproduces predominantly in a vegetative way due to the division of rhizomes that are spreading by the melt water during the period of abundant snow melting, but in some locations seed renewal is noted. Seeds are small, elongated. The seed shape is curved-pin-shaped. The seeds surface is bare, longitudinally wrinkled. The seed scar is small, slightly protruding, basal, rounded. Seed color is from light brown to hazel. The length is $2.13 \pm 0.16 \mathrm{~mm}, \mathrm{Cv}=15.7 \%$; min-max $-1.65-2.78 \mathrm{~mm}$, the width is $0.48-0.81 \mathrm{~mm}$ $(0.59 \pm 0.07 \mathrm{~mm}, \mathrm{Cv}=17.5 \%)$. The weight of 1000 seeds is $0.208-0.239 \mathrm{~g}$. Once in the soil, ripened seeds undergo natural stratification over the next 7-8 months. Germination rate of $R$. rosea seeds in lab conditions at $18^{\circ} \mathrm{C}$ in three replications was $51 \%$.

Plantlets (Fig. 5(p)) appear at the end of May and beginning of June. Emergence of seeding is epigeous. The cotyledons are light green, bare, succulent $3,2 \pm 0.09$ $\mathrm{mm}$ long, $1.8 \pm 0.06 \mathrm{~mm}$ wide. The leaf blade is ovalovoid, have short petiole up to $2.8 \mathrm{~mm}$ long, rounded at the apex, sharply tapered at the base turning into a short petiole. The hypocotyl is $3.2 \pm 0.07 \mathrm{~mm}$ long, up to $1.1 \pm 0.03 \mathrm{~mm}$ thick, pale green, the basal part is thickened, sharply passes into the embryonic (primary) root. The main root reaches $2.3 \pm 0.08 \mathrm{~cm}$ by the time the cotyledons dry up. Cotyledons persist until mid or late July. In the second and the third months after germination of the seed, this age condition ends.

At the end of July and beginning of August the species pass into juvenile state (Fig. 5j). Plants in this phase are characterized by the formation of leaf rosette of 2.6 \pm 0.04 leaves, the presence of a crown bud and 1-2 auxillary buds of an open type. The part of the growth sprout (rhizome) does not die off after the end of the vegetation season, but becomes perennial, from which the rhizome is subsequently formed. The seedlings end the juvenile phase at the age of 2-3 years old and less often.

Immature phase (Fig. 5(im)) is characterized by the growth of vegetative stems of normal type in the structure of medial sprout. The medial sprout of $7,2 \pm 0.12 \mathrm{~cm}$ height has $6,9 \pm 0.21$ pieces of natural leaves. The leaves are set by turn, the leaf blade is elongated-ellipsoid at the base and smoothly tapers into a short petiole. The crown and lateral buds of the growing sprout are of a closed type. The growth part of the rhizome is $2.4 \pm 0.2 \mathrm{~cm}$ in length and $0.6 \pm 0.03 \mathrm{~cm}$ in thickness. Rhizome branching is observed. The root system is well developed, in the horizontal projection is $2.8 \pm 0.08 \mathrm{~cm}$ and in the vertical projection $12.1 \pm$ 


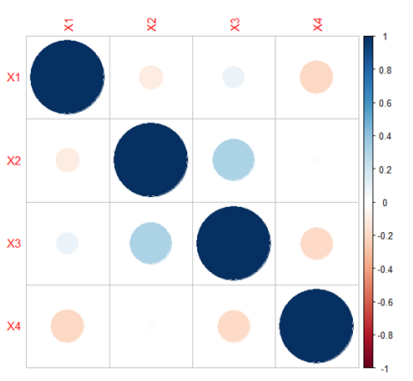

P1

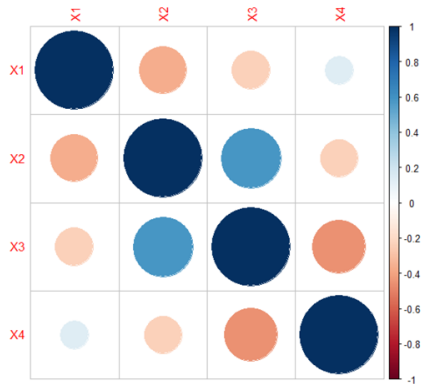

P4

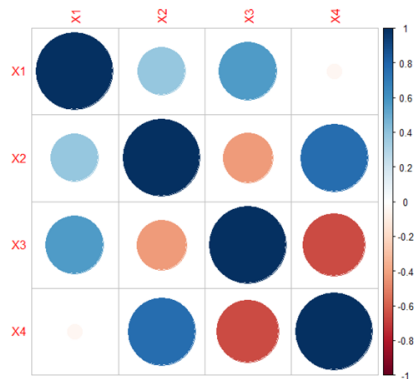

P7

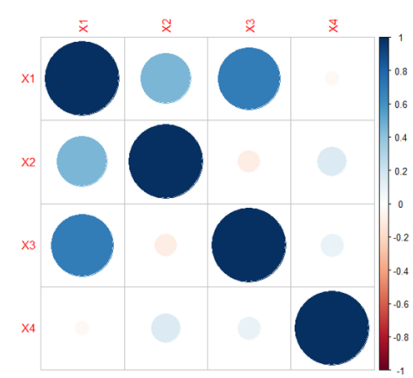

P2

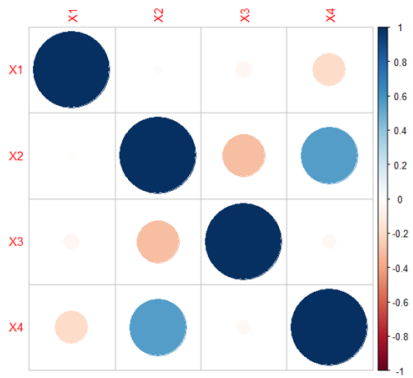

P5

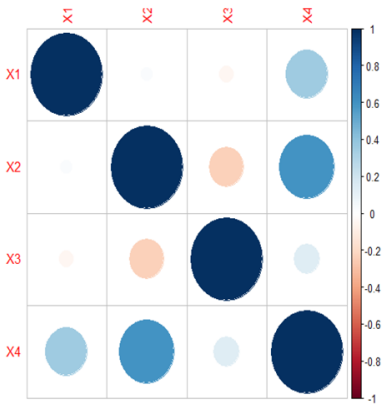

P8

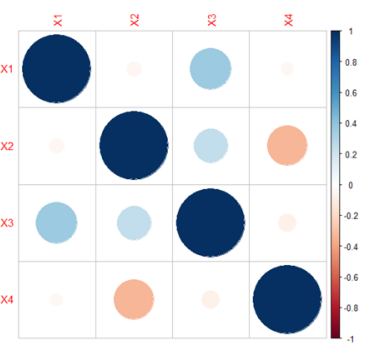

P3

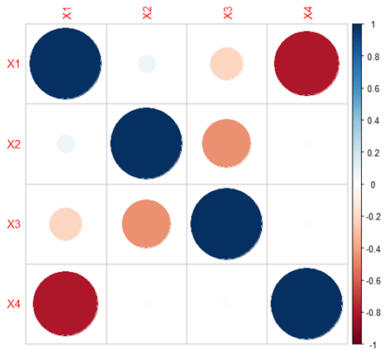

P6

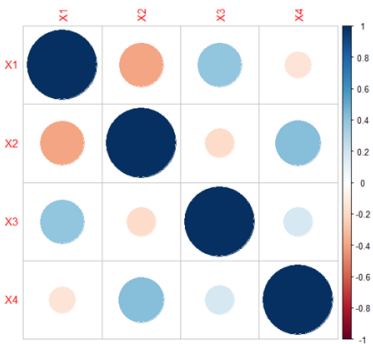

P9

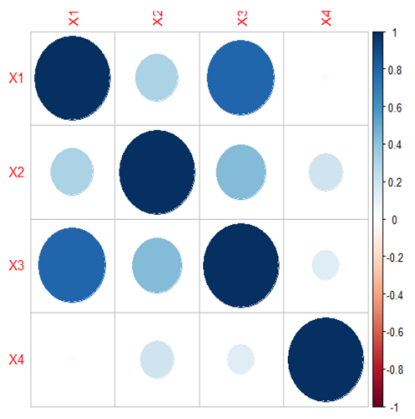

P10

Fig. 4 Correlation analysis of morphometric parameters and quantitative indicators of specimens within P1-P10 populations. Correlations with P $<0.05$ are highlighted in color. The color indicates either positive (blue) or negative (red) correlation. (X1: Number of adult specimens per $1 \mathrm{~m}^{2}$; X2: Height of generative species at the time of blooming $(\mathrm{cm})$; X3: The number of sprouts per a specimens (pcs); X4: Inflorescence diameter (cm)) 


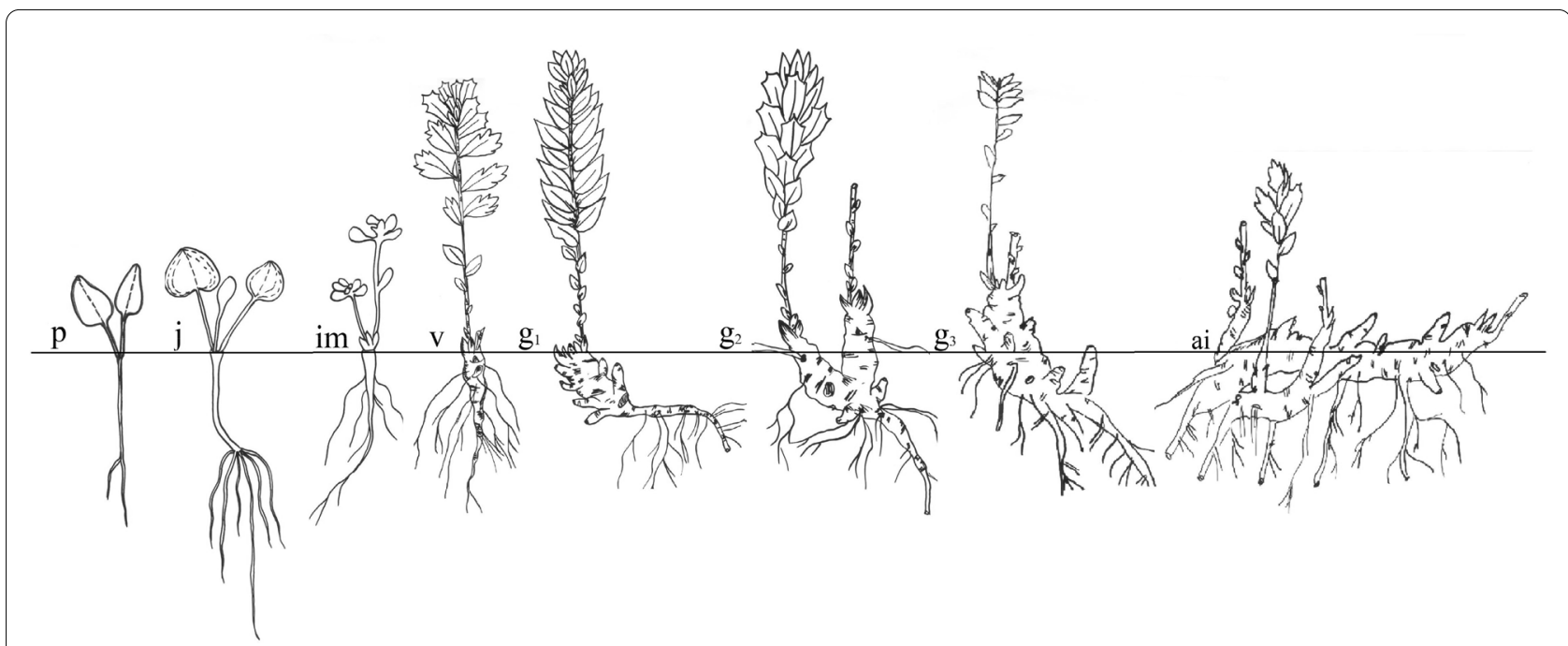

Fig. 5 Ontogenesis of R. rosea: p: plantlets; j: juvenile; im: immature, v: virginile, g1: young generative, g2: mature generative; g3: old generative; a.i.: ageing individuals

$1.56 \mathrm{~cm}$ (deepened). In the primordial state, plants sustain on average 2 vegetation seasons. In the future, the plants move to the next age state.

Virginal phase (Fig. 5(v)) might be seen for 5-7 year and starts with the branching of the medial sprout of branching of the medial sprout of the rhizome with the development of a significant number of lateral sprouts of the first order with the development of stems on them. The plants in this age state are $14 \pm 1.31 \mathrm{~cm}$ in height. The rhizome has $3,6 \pm 0.07$ pieces of stems of the first order. The medial sprout of the rhizome and some lateral sprouts are $6.2 \pm 0.06 \mathrm{~cm}$ long at the base and $0.83 \pm 1.2 \mathrm{~cm}$ across. The root system is well developed, $10.2 \pm 1.8 \mathrm{~cm}$ in horizontal projection and $16 \pm$ $2.2 \mathrm{~cm}$ in vertical projection. The primary root is about $1.8 \pm 0.06 \mathrm{~cm}$ thick.

The plants start the young generative phase (Fig. 5(g1)) at the age of 8-11 years. Generative stems are formed in the sprout. Young plants usually generate $2.8 \pm 0.06$ pieces of generative stems with a depleted inflorescence of $1.8 \pm 0.02$ flowers and $8,2 \pm 2.6$ vegetative stems in their first two years. Plants at the age of 8-10. more often at 12 years begin to form generative stems on the sprouts of the rhizome of the first type. The rhizome of the horizontal projection is $3.2 \pm$ $0.9 \mathrm{~cm}$ thick and $16.3 \pm 0.8 \mathrm{~cm}$ long. Plants are dioecious. The flowers are unisexual, yellow, four-membered (less often five-membered), small ( $3.2 \pm 0.06 \mathrm{~mm}$ long), collected in the final dense multi-flowered corymbose inflorescences. The number of flowers in an inflorescence are $6.3 \pm 1.8$ having a diameter of $4.8 \pm 0.35 \mathrm{~cm}$. The height of the plant is $30 \pm 1.8 \mathrm{~cm}$. In this age state, stems begin to form on the sprouts of second-order rhizomes. This age-related condition ends at 18-22 years.

The mature generative individuals (Fig. 5(g2)) include plants of 22-30 years, characterized by a powerful development of $43 \pm 2.1 \mathrm{~cm}$ in height. In this state there is an intensive development of the stems on the medial sprout of the rhizome and sprouts of the first and second types. Such individuals have $35 \pm 3.6$ pcs of generative and 42 \pm 2.8 pcs of vegetative stems. The inflorescence has 10.6 \pm 1.7 flowers being $5.2 \pm 0.35 \mathrm{~cm}$ in diameter. In this phase abundant flowering and fruiting and clone formation was observed. Particulation and clone formation are observed.

The plants start old generative phase (Fig. 5(g3)) at the age of 30-40 years. In this state, there is a noticeable predominance of the vegetative stems up to $68 \pm 3.9 \mathrm{pcs}$ and the formation of a significant number of weakened generative stems $52 \pm 2.8 \mathrm{pcs}$. The inflorescence is composed usually of $6.2 \pm 0.12$ flowers, having $3.8 \pm 0.35 \mathrm{~cm}$ in diameter. We observed here the beginning of the rhizome sprout decline and the formation of extensive foci of the main root necrosis and medial sprout of the rhizome. Also, mass dying of rhizomes' sprout of the first order is typical in this age phase.

Ageing individuals (Fig. 5(a.i.)) are very rare. It is pretty hard to define the age of this species. According to our data, specimens start this phase at the age of 50-55 years. In this state, extensive foci of necrosis appear almost along the entire length of the main rhizome and its disintegration into separate girders can be seen. There are frequent cases of dying of the adventitious roots and of the first-order rhizome sprouts. The bushes easily break 
up into 3-6 clones, form new plants and spread over the population area.

\section{Floristic composition of the $R$. rosea communities}

As a result of data processing of our field studies and herbarium collections, in the floristic composition of $R$. rosea communities we registered 140 species belonging to 39 families and 104 genera, which is $14 \%$ of the Altai highland flora (AHF), where 996 species of vascular plants from 325 genera and 80 families are registered (Table 2). Herbarium collections are kept in the herbarium of the NUR and Alt.

The systematic analysis of the floristic composition of $R$. rosea communities showed that leading families in terms of the species frequencies are Poaceae Barnhart (12\%), Ranunculaceae Juss. (10\%), Asteraceae Bercht. \& J.Presl (9\%), Rosaceae Juss. (7\%), Caryophyllaceae Juss. (5\%), Apiaceae Lindl. (4\%), Fabaceae Lindl. (4\%) and Polygonaceae Juss. (4\%) (Fig. 6). They account for 77 (55\%) species of the flora composition.

The most common 17 species in the floristic composition of the habitats are (occurrence IV-V): Schulzia crinita, Achillea ledebourii, Doronicum altaicum, Macropodium nivale, Hylotelephium telephium, Rhodiola algida, Carex capillaris, C. aterrima, C. stenocarpa, Euphorbia pilosa, Trifolium lupinaster, Deschampsia cespitosa, Festuca borissii, F. kryloviana, Delphinium elatum, Aquilegia flabellata, Ranunculus altaicus, Alchemilla altaica, 35 species are rather rare (occurrence I). The number of species in the composition of the flora range from 21 to $40 \%$ (II) - 59 species and from 41 to $60 \%$ (III) - 28 species (Fig. 7).

In the floral composition of $R$. rosea communities, all species are perennials. The analysis of life forms showed that tap root plants (30\%), brushy root plants (34\%), short rhizomatous plants (14\%), long rhizomatous plants (14), shrubs (7\%) prevail in communities with the participation of $R$. rosea (Fig. 8).

Data on the distribution of species by ecological groups, according to the classification of Kuminova A.V. (1960), showed that psychrophytes (32\%), mesophytes (28\%), mesopsychrophytes (11\%) and mesoxerophytes (7\%) are dominating in the floral composition of $R$. rosea communities (Fig. 9).

The chorological analysis shows that the Asian group (39\%), the Eurasian group (30\%), and the Holarctic species $(20 \%)$ are most abundant (Fig. 10).

Analysis of the life forms by Raunkiaer (1934) showed that in communities with $R$. rosea, the vast majority of species are Hemicryptophytes (74\%), a small amount of species are Mesophanerophytes (7\%),
Nanophanerophytes (8\%), Chamaephyts (7\%). Cryptophytes account for $4 \%$ (Fig. 11).

\section{Discussion}

In the studies of Vedernikova and Nikandrova (2000) interesting differences was found between two groups of populations $R$. rosea, when studying interpopulation variation which are populations timed to the mountain tundra belt on the one hand, and populations timed to near-snowy lawns and river meadows on the other hand. In the second group of populations, a tendency towards a clear predominance of features which characterize the general habit of the plant (height of sprouts, their number, leaf size, etc.) is noted. Therefore, these environmental conditions can be considered optimal for $R$. rosea. Our studies also confirmed this theory. In open, sparsely populated areas and along the valleys of mountain streams, individuals are significantly stunted (20$25 \mathrm{~cm}$ ), but have multi-stemmed bushes (30-50 pcs) and large inflorescences $(5.2-6 \mathrm{~cm}$ in diameter). The height of $R$. rosea individuals in the examined populations ranges from 24.42 to $49.29 \mathrm{~cm}$, the diameter of the inflorescence varies between 3.21 and $5.25 \mathrm{~cm}$. These parameters are within the normal range for the species (Eggli 2003).

In the studied region, $R$. rosea is found in different ecological conditions and altitudinal ranges of $1700-2400 \mathrm{~m}$ (from the upper limit of the forest belt to the tundra belt of the mountains). The wide range of habitats of the species is also confirmed by other researchers (Allen et al. 2014; Cuerrier and Ampong-Nyarko 2014; Fu et al. 2001).

Based on our study we can confirmed that $R$. rosea is present in the Southwestern and Southern Altai of the studied region, as well as on the Tarbagatai ridge. When reviewing the herbarium collections of $\mathrm{AA}$, one herbarium collection was found from the territory of the Kalbinsky ridge (Koktau mountains under the ridge of rocks 1440 m, singly, Snegirev V., 31. V. 1994 (AA)), but our studies did not confirm this location of the species. Perhaps an error could have been made in labeling, or this collection may be evidence of the former distribution of the species preserved in the relict complex "Sinegorskaya fir Grove" (Myrzagalieva 2006).

$R$. rosea plants are known to be long-lived perennials, but maximum ages in wild populations have not been studied (Brinckmanna et al. 2021). According to Nekratova and Nekratov (2005), the maximum age of $R$. rosea is 80 years. Our researches allowed us to establish the maximum age of $R$. rosea in the studied region at 55 years, after which the bushes easily disintegrate into 3-6 clones, forming new plants and spreading over the population area.

According to Revushkin (1988), 996 species of vascular plants from 325 genera and 80 families were registered in 
Table 2 Floristic composition of the studied R. rosea study plots

\begin{tabular}{|c|c|c|c|c|c|c|}
\hline № & The species name & $\begin{array}{l}\text { Occurrence } \\
\text { of species }\end{array}$ & $\begin{array}{l}\text { Life forms } \\
\text { (Raunkiaer 1934) }\end{array}$ & $\begin{array}{l}\text { Life forms } \\
\text { (Serebryako, } \\
\text { 1962) }\end{array}$ & $\begin{array}{l}\text { Ecological } \\
\text { groups }\end{array}$ & Area \\
\hline \multicolumn{7}{|c|}{ Amaryllidaceae } \\
\hline 1. & Allium schoenoprasum L. & III & C & Bbp & $\mathrm{HP}$ & euras. \\
\hline 2. & Allium flavidum Ledeb. & । & C & $\mathrm{Bbp}$ & MP & as. \\
\hline \multicolumn{7}{|c|}{ Apiaceae } \\
\hline 3. & Neogaya simplex (L.) Meisn. & $\|$ & $\mathrm{H}$ & Tp & $P$ & euras. \\
\hline 4. & Angelica archangelica L. & III & $\mathrm{H}$ & Tp & M & as. \\
\hline 5. & Angelica decurrens (Ledeb.) B.Fedtsch. & $\|$ & $\mathrm{H}$ & Tp & M & as. \\
\hline 6. & Bupleurum multinerve DC. & $\|$ & $\mathrm{H}$ & Tp & MP & as. \\
\hline 7. & Sajanella monstrosa (Stephan ex Schult.) Soják & III & $\mathrm{H}$ & $T p$ & P & as. \\
\hline 8. & Schulzia crinita (Pall.) Spreng. & IV & $\mathrm{H}$ & Tp & P & as. \\
\hline \multicolumn{7}{|c|}{ Asteraceae } \\
\hline 9. & Aster alpinus L. & $\|$ & $\mathrm{H}$ & Tp & $x$ & holarc. \\
\hline 10. & Achillea millefolium $\mathrm{L}$. & $\|$ & $\mathrm{H}$ & Lrp & M & holarc. \\
\hline 11. & Saussurea alpina (L.) DC. & $\|$ & $\mathrm{H}$ & Lrp & $\mathrm{P}$ & holarc. \\
\hline 12. & Senecio nemorensis L. & । & $\mathrm{H}$ & Brp & M & euras. \\
\hline 13. & Solidago virgaurea $\mathrm{L}$. & III & $\mathrm{H}$ & Brp & M & euras. \\
\hline 14. & Hieracium virosum Pall. & $\|$ & $\mathrm{H}$ & $T p$ & MX & euras. \\
\hline 15. & Crepis chrysantha (Ledeb.) Turcz. & । & $\mathrm{H}$ & Srp & P & euras. \\
\hline 16. & Saussurea latifolia Ledeb. & $\|$ & $\mathrm{H}$ & Lrp & M & as. \\
\hline 17. & Achillea ledebourii Heimerl & IV & $\mathrm{H}$ & Brp & M & as. \\
\hline 18. & Frolovia frolowii (Ledeb.) Raab-Straube & $\|$ & $\mathrm{H}$ & Tp & MP & as. \\
\hline 19. & Leuzea carthamoides (Willd.) DC. & $\|$ & $\mathrm{H}$ & $T p$ & MP & as. \\
\hline 20. & Doronicum altaicum Pall. & IV & $\mathrm{H}$ & Tp & P & as. \\
\hline \multicolumn{7}{|c|}{ Berberidaceae } \\
\hline 21. & Berberis sibirica Pall. & । & N & S & MPt & cent.as \\
\hline \multicolumn{7}{|c|}{ Betulaceae } \\
\hline 22. & Betula glandulosa Michx. (=B. rotundifolia Spach) & III & N & S & P & euras. \\
\hline \multicolumn{7}{|c|}{ Boraginaceae } \\
\hline 23. & Myosotis scorpioides L. & $\|$ & $\mathrm{H}$ & Brp & $\mathrm{H}$ & holarc. \\
\hline 24. & Myosotis sylvatica Ehrh. ex Hoffm. & । & $\mathrm{H}$ & Brp & M & euras. \\
\hline 25. & Eritrichium villosum (Ledeb.) Bunge & । & $\mathrm{H}$ & $T p$ & P & euras. \\
\hline \multicolumn{7}{|c|}{ Brassicaceae } \\
\hline 26. & Cardamine macrophylla Willd. & $\|$ & C & Lrp & $\mathrm{HP}$ & as. \\
\hline 27. & Macropodium nivale (Pall.) W.T.Aiton & IV & $\mathrm{H}$ & Tp & P & as. \\
\hline \multicolumn{7}{|c|}{ Campanulaceae } \\
\hline 28. & Campanula cervicaria $\mathrm{L}$. & I & $\mathrm{H}$ & Tp & M & euras. \\
\hline \multicolumn{7}{|c|}{ Caprifoliaceae } \\
\hline 29. & Patrinia sibirica (L.) Juss. & $\|$ & $\mathrm{H}$ & $T p$ & $\mathrm{XPt}$ & as. \\
\hline 30. & Valeriana dubia Bunge & । & C & Brp & MX & as. \\
\hline 31. & Lonicera caerulea subsp. altaica (Pall.) Gladkova & ॥ & M & S & MP & as. \\
\hline \multicolumn{7}{|c|}{ Caryophyllaceae } \\
\hline 32. & Dichodon cerastoides (L.) Rchb. & । & $\mathrm{Ch}$ & Srp & P & holarc. \\
\hline 33. & Cherleria biflora (L.) A.J.Moore \& Dillenb. & । & $\mathrm{Ch}$ & $T p$ & $P$ & holarc. \\
\hline 34. & Sabulina verna (L.) Rchb. & $\|$ & $\mathrm{H}$ & Tp & P & holarc. \\
\hline 35. & Sagina saginoides (L.) H.Karst. & $\|$ & $\mathrm{Ch}$ & $T p$ & $P$ & holarc. \\
\hline 36. & Dianthus superbus L. & ॥ & $\mathrm{H}$ & Lrp & M & euras. \\
\hline 37. & Cerastium davuricum Fisch. ex Spreng. & III & $\mathrm{H}$ & Tp & $\mathrm{HP}$ & as. \\
\hline 38. & Silene bungei Bocquet & 1 & $\mathrm{H}$ & Tp & $P$ & as. \\
\hline
\end{tabular}


Table 2 (continued)

№ The species nam

Occurrence Life form

Life forms

Ecological Area

1962)

\section{Crassulaceae}

39. Hylotelephium telephium (L.) H.Ohba

40. Phedimus hybridus (L.) Hart

41. Hylotelephium ewersii (Ledeb.) H.Ohba

42. Rhodiola algida (Ledeb.) Fisch. \& C.A.Mey.

Cupressaceae

43. Juniperus communis var. saxatilis Pall. (=J. sibirica Burgsd.) Cyperaceae

44. Eriophorum angustifolium Honck.

45. Carex capillaris L.

46. Carex aterrima Hoppe

47. Carex pediformis var. macroura (Meinsh.) Kük.

48. Carex curaica Kunth

49. Carex stenocarpa Turcz. ex V.I.Krecz.

50. Carex altaica (Gorodkov) V.I.Krecz.

Ericaceae

51. Vaccinium myrtillus L.

IV H

Euphorbiaceae

52. Euphorbia pilosal.

Fabaceae

53. Hedysarum neglectum Ledeb. (=Hedysarum austrosibiricum B.Fedtsch.) III

54. Oxytropis purpurea (Bald.) Markgr.

55. Trifolium lupinaster $\mathrm{L}$.

56. Hedysarum theinum Krasnob.

57. Thermopsis alpina (Pall.) Ledeb.

58. Oxytropis alpina Bunge

Gentianaceae

59. Swertia obtusa Ledeb.

60. Gentiana algida Pall.

61. Gentiana grandiflora Laxm.

Geraniaceae

62. Geranium albiflorum Ledeb.

Juncaceae

63. Luzula spicata (L.) DC.

Lamiaceae

64. Dracocephalum ruyschiana L.

65. Dracocephalum peregrinum L.

66. Dracocephalum grandiflorum L.

Liliaceae

67. Gagea serotina (L.) Ker Gawl. (=Lloydia serotina (L.) Rchb.)

Lycopodiaceae

68. Diphasiastrum alpinum (L.) Holub

Melanthiaceae

69. Veratrum lobelianum Bernh.

Montiaceae

70. Claytoniajoanneana Schult.

Onagraceae

71. Epilobium palustre L.
III

॥

IV

N

$\sqrt{20}$

V

IV

$\mathrm{H}$

$\mathrm{Ch}$

$\mathrm{Ch}$

$\mathrm{Ch}$

N

H

$\mathrm{H}$

$\mathrm{H}$

$\mathrm{H}$

$\mathrm{H}$

$\mathrm{H}$

C

II

Ch

H

$\mathrm{H}$

$\mathrm{H}$

$\mathrm{H}$

H

H

H

$\mathrm{H}$

$\mathrm{H}$

$\mathrm{H}$

Ch

H

$\mathrm{H}$

C

H

$\mathrm{H}$

C

Ch

H

$\mathrm{H}$

H

III

$\begin{array}{lll}\text { Brp } & \text { M } & \text { euras } \\ \text { Srp } & \text { XPt } & \text { as. } \\ \text { Brp } & \text { MPt } & \text { as. } \\ \text { Tp } & P & \text { Alt. }\end{array}$

S

MP

euras.

Lrp

HP holarc.

HS

Brp

Srp

Brp

Srp

Lrp

H euras.

HP euras.

MX euras.

$\mathrm{H}$ as.

P as.

HP Alt

Ds MP holarc.

$\mathrm{Tp}$

XPt

tur.

$\mathrm{Tp}$

$\mathrm{Tp}$

srp

Tp

Lrp

$\mathrm{Tp}$

Lrp

Brp

Tp

Brp

Brp

$M$

euras.

$\mathrm{M}$

euras.

MX

euras.

as.

$M P$

as.

P as.

P Alt.

as.

as.

as.

as.

holarc.

Srp

Tp

Srp

M

$P$

P

M

P

euras.

$M$

as.

$X P t$

MP

as.

$\mathrm{Bp}$

P

holarc.

$\mathrm{Cm}$

P

holarc.

Brp

M

as.

Tp

P

as.

Srp

HP

holarc. 
Table 2 (continued)

\begin{tabular}{|c|c|c|c|c|c|c|}
\hline № & The species name & $\begin{array}{l}\text { Occurrence } \\
\text { of species }\end{array}$ & $\begin{array}{l}\text { Life forms } \\
\text { (Raunkiaer 1934) }\end{array}$ & $\begin{array}{l}\text { Life forms } \\
\text { (Serebryako, } \\
\text { 1962) }\end{array}$ & $\begin{array}{l}\text { Ecological } \\
\text { groups }\end{array}$ & Area \\
\hline 72. & Epilobium angustifolium L. & I & $\mathrm{H}$ & $\mathrm{Tp}$ & M & holarc. \\
\hline \multicolumn{7}{|c|}{ Orobanchaceae } \\
\hline 73. & Pedicularis oederi Vahl & III & $\mathrm{H}$ & $\mathrm{Tp}$ & P & holarc. \\
\hline 74. & Pedicularis violascens Schrenk & । & $\mathrm{H}$ & $T p$ & $\mathrm{XPt}$ & as. \\
\hline 75. & Pedicularis amoena Adams ex Steven & $\|$ & $\mathrm{H}$ & $T p$ & P & as. \\
\hline 76. & Pedicularis achilleifolia Stephan ex Willd. & I & $\mathrm{H}$ & $\mathrm{Tp}$ & $\mathrm{XPt}$ & as. \\
\hline \multicolumn{7}{|c|}{ Papaveraceae } \\
\hline 77. & Papaver nudicaule L. & III & $\mathrm{H}$ & $\mathrm{Tp}$ & MP & as. \\
\hline 78. & Papaver croceum Ledeb. & । & $\mathrm{H}$ & $T p$ & P & as. \\
\hline \multicolumn{7}{|c|}{ Pinaceae } \\
\hline 79. & Abies sibirica Ledeb. & I & M & T & M & euras. \\
\hline 80. & Larix sibirica Ledeb. & । & M & $\mathrm{T}$ & M & euras. \\
\hline 81. & Picea obovata Ledeb. & । & M & T & M & euras. \\
\hline 82. & Pinus sibirica Du Tour & । & M & $\mathrm{T}$ & M & euras. \\
\hline \multicolumn{7}{|c|}{ Plantaginaceae } \\
\hline 83. & Veronica densiflora Ledeb. & । & $\mathrm{H}$ & Lrp & $P$ & as. \\
\hline \multicolumn{7}{|c|}{ Poaceae } \\
\hline 84. & Deschampsia cespitosa (L.) P.Beauv. & IV & $\mathrm{H}$ & Brp & $\mathrm{H}$ & cosm. \\
\hline 85. & Anthoxanthum monticola (Bigelow) Veldkamp & । & $\mathrm{H}$ & Srp & M & cosm. \\
\hline 86. & Festuca rubra L. & III & $\mathrm{H}$ & Brp & HP & holarc. \\
\hline 87. & Poa alpigena Lindm. & $\|$ & C & Lrp & M & holarc. \\
\hline 88. & Festuca borissii Reverd. & IV & $\mathrm{H}$ & Brp & MP & holarc. \\
\hline 89. & Calamagrostis purpurea (Trin.) Trin. & $\|$ & $\mathrm{H}$ & Lrp & $\mathrm{H}$ & euras. \\
\hline 90. & Elymus repens (L.) Gould & $\|$ & C & Lrp & M & euras. \\
\hline 91. & Alopecurus pratensis $\mathrm{L}$. & $\|$ & C & Srp & M & euras. \\
\hline 92. & Dactylis glomerata L. & III & $\mathrm{H}$ & Brp & M & euras. \\
\hline 93. & Helictochloa hookeri (Scribn.) Romero Zarco & $\|$ & $\mathrm{H}$ & Brp & MX & euras. \\
\hline 94. & Phleum alpinum L. & $\|$ & $\mathrm{H}$ & Brp & P & euras. \\
\hline 95. & Poa sibirica Roshev. & । & $\mathrm{H}$ & Brp & MP & as. \\
\hline & Paracolpodium altaicum (Trin.) Tzvelev & । & $\mathrm{H}$ & Lrp & P & as. \\
\hline & Trisetum altaicum Roshev. & $\|$ & $\mathrm{H}$ & Brp & P & as. \\
\hline 98. & Festuca kryloviana Reverd. & IV & $\mathrm{H}$ & Brp & $P$ & as. \\
\hline 99. & Poa attenuata Trin. & III & $\mathrm{H}$ & Brp & MX & Alt. \\
\hline 100. & Koeleria altaica (Domin) Krylov & । & $\mathrm{H}$ & Brp & P & Alt. \\
\hline \multicolumn{7}{|c|}{ Polygonaceae } \\
\hline 101. & Bistorta vivipara (L.) Delarbre & III & $\mathrm{H}$ & Brp & HP & holarc. \\
\hline 102. & Oxyria digyna (L.) Hill & $\|$ & $\mathrm{H}$ & Lrp & MPt & holarc. \\
\hline 103. & Koenigia alpina (All.) T.M.Schust. \& Reveal & $\|$ & $\mathrm{H}$ & Tp & M & euras. \\
\hline 104. & Rumex acetosa L. & III & $\mathrm{H}$ & Tp & M & euras. \\
\hline 105. & Rumex scutatus L. & $\|$ & $\mathrm{H}$ & $\mathrm{Tp}$ & M & euras. \\
\hline 106. & Bistorta elliptica (Willd. ex Spreng.) V.V.Petrovsky, D.F.Murray \& Elven & III & $\mathrm{H}$ & Brp & P & euras. \\
\hline \multicolumn{7}{|c|}{ Primulaceae } \\
\hline 107. & Primula nivalis Pall. & । & $\mathrm{H}$ & Brp & HP & as. \\
\hline \multicolumn{7}{|c|}{ Ranunculaceae } \\
\hline 108. & Ranunculus lapponicus L. & $\|$ & $\mathrm{H}$ & Lrp & $\mathrm{H}$ & holarc. \\
\hline 109. & Caltha palustris L. & III & $\mathrm{H}$ & Brp & $\mathrm{H}$ & holarc. \\
\hline 110. & Thalictrum alpinum L. & । & $\mathrm{H}$ & Srp & $P$ & holarc. \\
\hline 111. & Delphinium elatum L. & IV & $\mathrm{H}$ & Srp & M & euras. \\
\hline
\end{tabular}


Table 2 (continued)

\begin{tabular}{|c|c|c|c|c|c|c|}
\hline № & The species name & $\begin{array}{l}\text { Occurrence } \\
\text { of species }\end{array}$ & $\begin{array}{l}\text { Life forms } \\
\text { (Raunkiaer 1934) }\end{array}$ & $\begin{array}{l}\text { Life forms } \\
\text { (Serebryako, } \\
\text { 1962) }\end{array}$ & $\begin{array}{l}\text { Ecological } \\
\text { groups }\end{array}$ & Area \\
\hline 112. & Thalictrum flavum L. & $\|$ & $\mathrm{H}$ & Brp & M & euras. \\
\hline 113. & Aconitum septentrionale Koelle & III & $\mathrm{H}$ & $\mathrm{Tp}$ & M & euras. \\
\hline 114. & Trollius altaicus C.A.Mey. & $\|$ & $\mathrm{H}$ & Srp & M & as. \\
\hline 115. & Anemonastrum narcissiflorum (L.) Holub & $\|$ & $\mathrm{H}$ & Srp & $M X$ & as. \\
\hline 116. & Aquilegia flabellata Siebold \& Zucc. & IV & $\mathrm{H}$ & Srp & MX & as. \\
\hline 117. & Callianthemum alatavicum Freyn & $\|$ & $\mathrm{H}$ & Srp & $P$ & as. \\
\hline 118. & Trollius lilacinus Bunge & । & $\mathrm{H}$ & Brp & $\mathrm{P}$ & as. \\
\hline 119. & Aconitum apetalum (Huth) B.Fedtsch. & III & $\mathrm{H}$ & Brp & MP & Alt. \\
\hline 120. & Aconitum glandulosum Rapaics & $\|$ & $\mathrm{H}$ & $\mathrm{Bbp}$ & MP & Alt. \\
\hline 121. & Ranunculus altaicus Laxm. & IV & $\mathrm{H}$ & Brp & $P$ & Alt. \\
\hline \multicolumn{7}{|c|}{ Rosaceae } \\
\hline 122. & Dasiphora fruticosa (L.) Rydb. & $\|$ & $\mathrm{N}$ & $\mathrm{S}$ & M & holarc. \\
\hline 123. & Spiraea media Schmidt & $\|$ & $\mathrm{N}$ & $\mathrm{s}$ & M & euras. \\
\hline 124. & Alchemilla altaica Juz. & IV & $\mathrm{H}$ & Srp & M & euras. \\
\hline 125. & Cotoneaster uniflorus Bunge & $\|$ & $\mathrm{N}$ & S & $\mathrm{P}$ & euras. \\
\hline 126. & Sibbaldia procumbens L. & III & $\mathrm{Ch}$ & Lrp & P & as. \\
\hline 127. & Dasiphora glabrata (Willd. ex Schltdl.) Soják & $\|$ & N & $\mathrm{S}$ & P & as. \\
\hline 128. & Dryas oxyodonta Juz. & III & $\mathrm{Ch}$ & Ds & P & as. \\
\hline 129. & Sanguisorba alpina Bunge & III & $\mathrm{H}$ & $\mathrm{Tp}$ & $P$ & as. \\
\hline 130. & Sibiraea laevigata (L.) Maxim. & $\|$ & N & $S$ & MX & Alt. \\
\hline \multicolumn{7}{|c|}{ Rubiaceae } \\
\hline 131. & Galium boreale L. & $\|$ & $\mathrm{H}$ & Lrp & M & holarc. \\
\hline \multicolumn{7}{|c|}{ Salicaceae } \\
\hline 132. & Salix lanata L. & $\|$ & $\mathrm{N}$ & $S$ & $P$ & holarc. \\
\hline 133. & Salix turczaninowii (Laksch.) & $\|$ & $\mathrm{N}$ & Ds & $P$ & euras. \\
\hline 134. & Salix rectijulis Ledeb. ex Trautv. & $\|$ & N & S & $P$ & as. \\
\hline \multicolumn{7}{|c|}{ Saxifragaceae } \\
\hline 135. & Saxifraga sibirica L. & । & $\mathrm{H}$ & Brp & $\mathrm{HP}$ & as. \\
\hline 136. & Micranthes punctata (L.) Losinsk. & $\|$ & $\mathrm{H}$ & $\mathrm{Tp}$ & $\mathrm{HP}$ & as. \\
\hline 137. & Bergenia crassifolia (L.) Fritsch & $\|$ & $\mathrm{H}$ & Lrp & MPt & as. \\
\hline \multicolumn{7}{|c|}{ Urticaceae } \\
\hline 138. & Urtica dioica L. & । & $\mathrm{H}$ & Lrp & M & euras. \\
\hline \multicolumn{7}{|c|}{ Violaceae } \\
\hline 139. & Viola biflora L. & $\|$ & $\mathrm{H}$ & Srp & MP & holarc. \\
\hline 140. & Viola altaica Ker Gawl. & III & $\mathrm{H}$ & $\mathrm{Tp}$ & $P$ & as. \\
\hline \multicolumn{7}{|c|}{$\begin{array}{l}\text { Occurrence of species: I - 0-20\%, II - 21-40\%, III - 41-60\%, IV - 61-80\%, V-81-100\% } \\
\text { Life forms according to Raunkiaer (1934): M - Mesophanerophytes, N - Nanophanerophytes, Ch - Chamaephyts, H - Hemicryptophytes, C - Crypto- } \\
\text { phytes } \\
\text { Life forms according to Serebryakov, (1962): T - tree; S - shrub; Hs - half-shrub; Ds - dwarfshrub; Lrp - long rhizomatous plant; Srp - short rhizoma- } \\
\text { tous plants; Bbp - bulbotuberiferous plants; Bp - bulbous plants; Tp -taproot plants; Brp - brushy root plants; Tsp - tussock plants; Cm - club-moss } \\
\text { Ecological groups of plants in relation to the temperature, moisture and ston nature of the substrate: H - hygrophytes, HP - hygropsychrophytes, GM } \\
\text { - hygromesophytes, M - mesophytes, MX - mesoxerophytes, MP - mesopsychrophytes, X- xerophytes, XPt - xeropetrophyte, P - psychrophytes, MPt - } \\
\text { mesopetrophytes } \\
\text { The groups of floral elements: cosm. - cosmopolitan; holarc. - Holarctic; euras. - Eurasian; as. - Asian; tur. - Turanian; Mtr - Mediterranean; Alt - Altai } \\
\text { (endemics of the Altai-Sayan botanical-geographical province) }\end{array}$} \\
\hline
\end{tabular}

the AHF, the species diversity of the floral composition of $R$. rosea communities was 140 species, which is $14 \%$ of the AHF flora. The composition based on the 10 most frequent families in terms of their quantities is almost identical to the composition of the leading families in AHF. However, their arrangement in descending order 


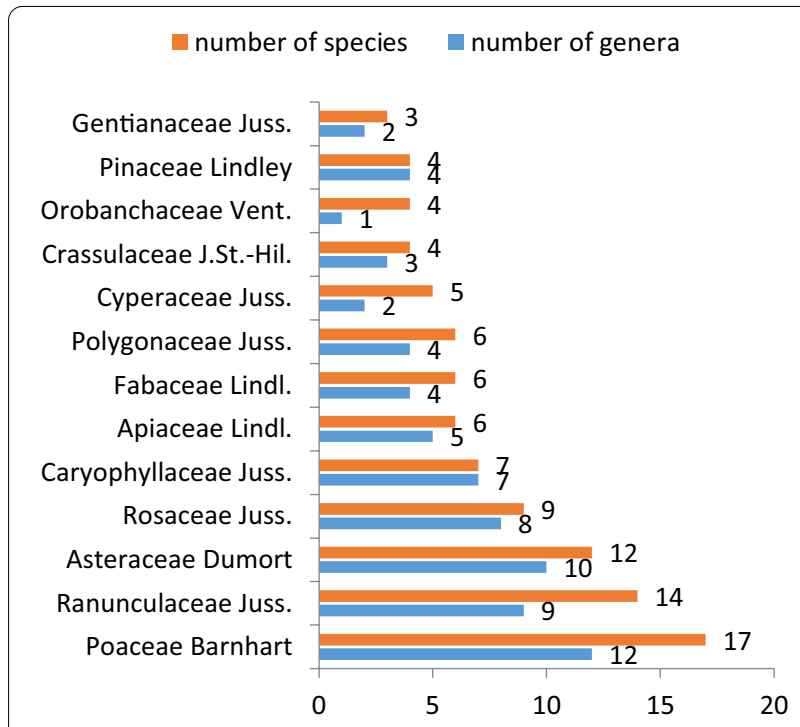

Fig. 6 Leading families with the number of genera and species within the composition of the $R$. rosea habitats

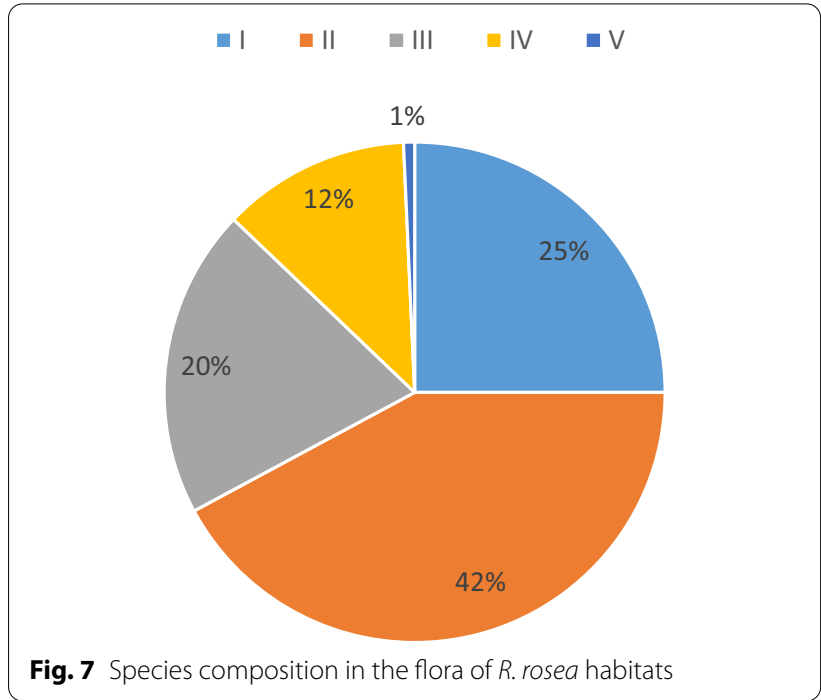

is somewhat different, which is due to the allocation of $R$. rosea to the redivided ecological groups. Communities with $R$. rosea are dominated by single and two species families, which characterizes the AHF flora (Sofronov et al. 2016), the Western Sayan (Kamelin 2016) and the arctic floras which develop in extreme habitat conditions and indicates the complicacy of the floral genesis process (Sofronov et al. 2016). The analysis of the genera spectrum accords well with the composition of the AHF leading genera (Revushkin 1988), where Carex, Aconitum, Dracocephalum, Festuca, Pedicularis, Poa, Salix genera prevail.

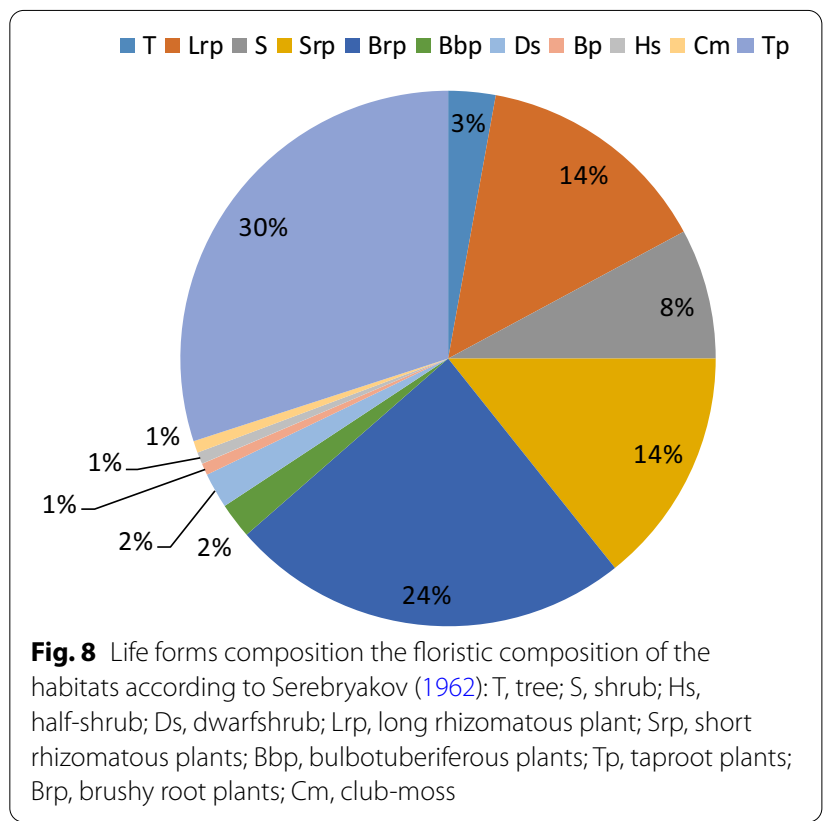

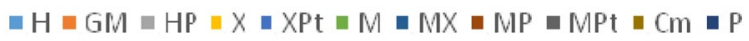

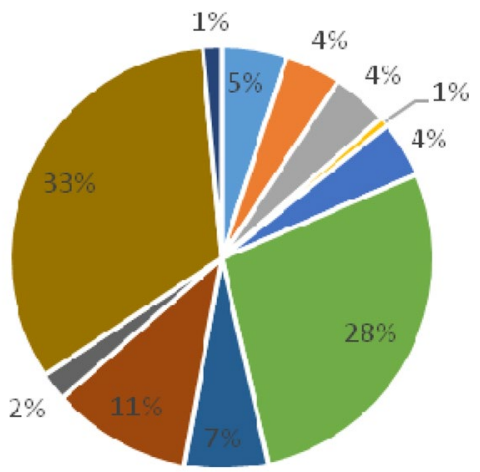

Fig. 9 Composition of the ecological groups in the flora of the $R$. rosea habitats: $\mathrm{H}$, hygrophytes; $\mathrm{GM}$, hygromesophytes; $\mathrm{HP}$, hygropsychrophytes; $\mathrm{X}$, xerophytes; $\mathrm{XPt}$, xeropetrophyte; $\mathrm{MX}$, mesoxerophytes; MP, mesopsychrophytes; $X$, xerophytes; XPt, xeropetrophyte; P, psychrophytes; MPt, mesopetrophytes

According to Revushkin (1988) it is enough to consider in the ecological analysis of highlands the humidity and the type of the substrate. No need of taking into account the temperature, the salinity or the soil fertility. However, we consider that the classification of ecological groups presented by Kuminova (1960) is well applicable for the highland flora analysis and the temperature regime is the crucial feature of the highlands. Despite that, we agree that it is inappropriately to allocate groups due to their salinity and soil fertility. The 

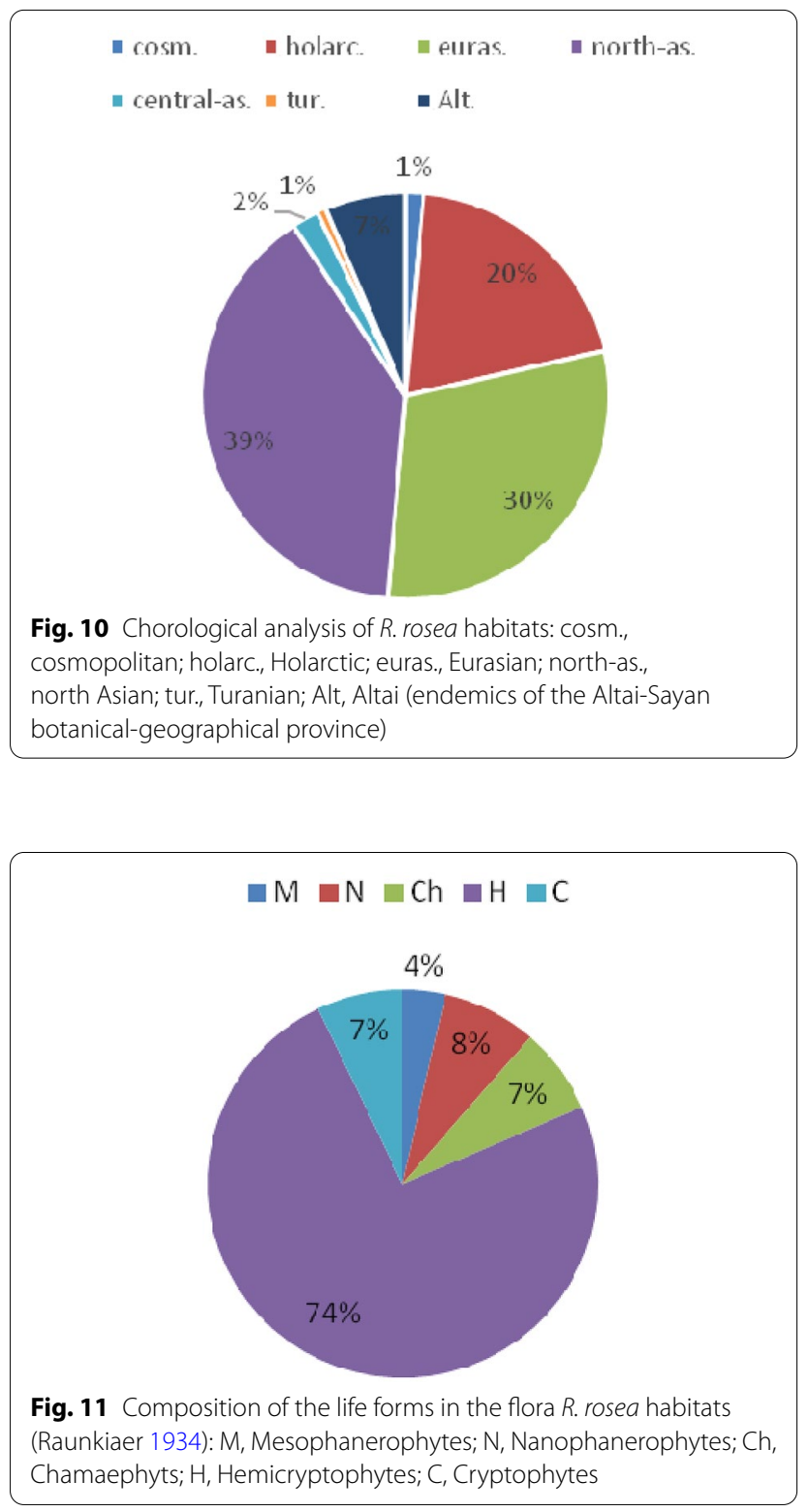

data showed that the composition of the flora is dominated by psychrophytes, mesophytes, mesopsychrophytes and mesoxerophytes. These groups account for $109(78 \%)$ species of the total floristic composition of the $R$. rosea communities. In general, this distribution of species by ecological groups is considered characteristic for the flora of the highlands.

The percentage of the chorological groups differs somewhat from the AHF, however, the leading groups nevertheless converge. It should be noted that a significant excess of the Eurasian group was detected, (30\%) compared to the AHF (14.4\%), and the participation of Asian species is in the opposite way lower (39\%) than the AHF (62\%). The distribution of species by life forms is in good agreement with the AHF flora.

\section{Conclusions}

In general, the state of $R$. rosea populations in the studied region should be considered satisfactory. In the surveyed populations anthropogenic influence was not observed, apparently because of difficult accessibility of the habitats. The main limiting factor is the low competitiveness of the species within the communities. When the habitats are overgrown with herbaceous-grass vegetation, populations of $R$. rosea are forced to gradually migrate to less overgrown areas, or fall out of the phytocenosis. All surveyed populations are maintained mainly by vegetative reproduction. Seed renewal is low as a result of seedlings dying in the early stages of development due to extreme habitat conditions.

\section{Abbreviations}

PC: Projective cover; CIS: Commonwealth of Independent States; WHO: World Health Organization; POWO: Plants of the World Online; AHF: Altai highland flora.

\section{Acknowledgements}

The authors would like to express thank Sumbebayev Aidar at al-Farabi Kazakh National University for their invaluable assistance (geographic map of population distribution).

\section{Authors' contributions}

"Conceptualization, SK and MZ; methodology, SK; software, MK; validation, $\mathrm{Kl}$, $\mathrm{MZ}$ and SK; formal analysis, SK; investigation, SK, MZ; resources, DA; data management, SK; writing—original draft preparation, SK, MZ, Kl; writing —review and editing, MK; visualization, JK; supervision, GS and SM; project administration, SK. All authors read and approved the final manuscript.

\section{Funding}

This research has been funded by the Science Committee of the Ministry of Education and Science of the Republic of Kazakhstan (Grant No. AP09561639). The study was also supported by the Ministry of Ecology, Geology and Natural Resources of the Republic of Kazakhstan (Program: Ecological and introduction analysis of collection funds of the State Botanical Gardens and screening of natural flora for the development of scientifically justified recommendations on the range of plants for landscaping cities and settlements in various natural zones of Kazakhstan. The research is partially funded by UNDP (contract number 2021-066 s/a).

\section{Availability of data and materials}

The data used and analyzed in this study can be provided from the respective author for scientifc, non-proft purpose.

\section{Declarations}

Ethics approval and consent to participate

Not applicable, the study involves no human participants.

\section{Consent for publication}

Not applicable.

\section{Competing interests}

The authors declare no conflict of interest. 


\section{Author details}

1 «Astana Botanical Garden» branch of the Republican State Enterprise on the right of economic management "Institute of Botany and Phytoinroduction", Nur-Sultan, Kazakhstan. ${ }^{2}$ Al-Farabi Kazakh National University, Almaty, Kazakhstan. ${ }^{3}$ Republican State Enterprise "Altai Botanical Garden", Ridder, Kazakhstan. ${ }^{4}$ Republican state enterprise on the right of economic management "Institute of Botany and Phytointroduction" of the Committee of Forestry and Wildlife of the Ministry of Ecology, Geology and Natural Resources of the Republic of Kazakhstan, Nur-Sultan , Republic of Kazakhstan.

\section{Received: 31 May 2021 Accepted: 25 October 2021}

\section{Published online: 07 November 2021}

\section{References}

Aiello N, Bontempo R, Vender C, Innocenti G, Dall'Acqua S (2013) Morphologi$\mathrm{cal}$ and qualitative characteristics of Rhodiola rosea $\mathrm{L}$. wild populations of Trentino, Italy. J Med Spice Plants 18(1):41-45

Allen D, Bilz M, Leaman DJ, Miller RM, Timoshyna AJ (2014) Window European Red List of Medicinal Plants Publications Office of the European Union, Luxembourg, p 13. https://doi.org/10.2779/907382

Artemov IA (2020) Floras of the archatinskoe and chernovinskoe forestries of the Katon-karagay state national nature park (the Republic of Kazakhstan). Acta Biologica Sibirica 6:107-138. https://doi.org/10.3897/abs.6. e53162

Bernard R (2016) Rhodiola rosea in Packaged Food and Beverages. Global Analysis Report Agriculture and Agri-Food Canada, Ottawa, Ontario

Borisova AG (1939) Orpine family - Crassulaceae DC. USSR flora, vol 9. pp 8-134

Brinckmann JA, Cunningham AB, David EV, Harter, (2021) Running out of time to smell the roseroots: Reviewing threats and trade in wild Rhodiola rosea L. J Ethnopharmacol. https://doi.org/10.1016/j.jep.2020.113710

Buchwald W, Mordalski R, Kucharski WA, Gryszczyńska A, Adamczak A (2015) Effect of fertilization on roseroot (Rhodiola rosea L.) yield and content of active compounds. Acta Sci Pol Hortorum Cultus 14(2):109-121

Buse J, Šlachta M, Sladecek FXJ, Pung M, Wagner T, Entling MH (2015) Relative importance of pasture size and grazing continuity for the longterm conservation of European dung beetles. Biological Conservation 187:112119. https://doi.org/10.1016/j.biocon.2015.04.011

Bykov BA (1970) Introduction to phytocenology (Almaty, Kazakhstan). KazSSR Academy of Science Publishing House, p 226

Chadburn H (2014) Rhodiola rosea. The IUCN Red List of Threatened Species 2014: e.T201554A55685155. Downloaded on 05 April 2021 https://www. iucnredlist.org/species/201554/55685155

Cuerrier AK, Ampong-Nyarko (eds) (2014) Rhodiola rosea. CRC Press, Boca Raton

Cunningham AB, Li HL, Luo P, Zhao WJ, Long XC, Brinckmann JA (2020) There "ain't no mountain high enough"? The drivers, diversity and sustainability of China's Rhodiola trade. J Ethnopharmacol 252:112379. https://doi.org/ 10.1016/j.jep.2019.112379

Eggli U (ed) (2003) Illustrated Handbook of Succulent Plants. Crassulaceae, Springer, Berlin, pp 223-224

Ferakova V, Maglocky S, Marhold K (2001) Cerveny zoznam papradorastov a semennych rastlin Slovenska (December 2001) In: Baláz, D. a goal. (eds.): Cerveny Zoznam Rastlin a Zivocichov Slovenska. Bretavaava / Banske Bystrija. Ochrana prírody, 20 (Suppl.), pp 44-77

Fu F, Ohba H, Gilbert MG (2001) Crassulaceae candolle Flora of China, vol 8. (Brassicaceae through Saxifragaceae). Science Press and Missouri Botanical Garden Press, Beijing and St. Louis, pp 251-268

Fusani P (2019) Research experiences on Plant Genetic Resources of medicinal species at the Forestry and Wood Research Center in Trento opportunities and challenges in light of the new law on medicinal plants

Golubev VN, Molchanov EF (1978) Methodical instructions for populationquantitative and ecological-biological study of rare, endangered and endemic plants of Crimea. Yalta, p 41

Grulich V (2012) Red List of vascular plants of the Czech Republic: 3rd edition. - Preslia 84: 631-645

György Z, Pedryc A, Fjelldal E, Aspholm PE, Ladányi M (2013) Genetic diversity of roseroot (Rhodiola rosea) in North-Norway. Biochem Syst Ecol 50:361-367. https://doi.org/10.1016/j.bse.2013.05.009
György Z, Szabó M, Pedryc A, Bacharov D (2012) Genetic diversity within and among populations of roseroot (Rhodiola rosea L.) Based on molecular markers. Notulae Botanicae Horti Agrobotanici Cluj-Napoca 40(2):266. https://doi.org/10.15835/nbha4028212

György Z, Vouillamoz J, Ladányi M, Pedryc A (2014) Genetic survey of Rhodiola rosea L. Populations from the Swiss Alps based on SSR markers. Biochem Syst Ecol 54:137-143. https://doi.org/10.1016/j.bse.2014.01.012

Hou Y, Lou A (2011) Population genetic diversity and structure of a naturally isolated plant species, rhodiola dumulosa (crassulaceae). PLoS ONE. https://doi.org/10.1371/journal.pone.0024497

Isayev EB (1993) Summary of the flora of the Southern Altai ridge (Almaty). Gylym 125

IUCN (2020) The IUCN Red List of Threatened Species. Version 2019-3

Ivanova MM (1979) Orpine family - Crassulaceae. Central Siberia flora; Novosibirsk. vol 1. pp 417-420

Karpukhin MY, Abramchuk AV (2020) Morpho-biological features of rosewort (Rhodiola rosea L.) under the conditions of introduction. E3S Web of Conferences, vol 176, https://doi.org/10.1051/e3sconf/202017603009

Kozyrenko MM, Artuikova EV, Pozdnyakova TE (2018) Genetic diversity of species of rhodiola (r. Rosea, r. Integrifolia, r. Stephanii и r. Pinnatifida) according to the polymorphism of intergenic spacers of chloroplast DNA. Agric Sci Agronomy 1(50):47-52

Kubentayev SA, Suleimenov AN, Kotukhov JA, Danilova AN, Sumbembayev AA (2018) Phytocenotic characteristics and stocks of the main medicinal plants of the south-western altai (East Kazakhstan). EurAsian J BioSci 12(2):355-368

Kubentayev SA, Kotukhov YuA, Danilova AN, Suleimenov AN, Sumbembayev AA (2019) Phytocoenotic Structure and Stocks of Main Medical Plants in Southern Part of Altai Mountain System (East Kazakhstan). J Comput Theor Nanosci 16(13):2822-2834. https://doi.org/10.1166/jctn.2019.8136 Kuminova AV (1960) Vegetation cover of Altai. Novosibirsk, p 449

Li Y-C, Wen J, Ren Y, Zhang J-Q (2019) From seven to three: Integrative species delimitation supports major reduction in species number in Rhodiola section Trifida (Crassulaceae) on the Qinghai-Tibetan Plateau. Taxon 68:268-279. https://doi.org/10.1002/tax.12052

Matthys K, Julsing J, Quax W, Kayser O (2007) The Engineering of medicinal plants: prospects and limitations of medicial plant biotechnology. Medicinal Plant Biotechnology from Basic Research to Industrial Applications Weinheim, Germany. Wiley-VCH/Vergal GmbH \& Co., pp 1-8. https://doi. org/10.1002/9783527619771.ch1

Metzing D, Hofbauer N, Ludwig G, Matzke-Hajek G (eds) (2018) Rote Liste gefährdeter Tiere, Pflanzen und Pilze Deutschlands. Volume 7: Plants. Nature Conservation and Biological Diversity Issue 70(7), Federal Agency for Nature Conservation, Bonn-Bad Godesberg https://doi.org/10.19213/ 972172/

Moryakina VA, Sviridova TP, Belyaeva TN, Stepanuk GYa, Amelchenkov VP, Zinner NS (2008) Conservation of plant biodiversity flora from Siberia botanical garden. Tomskova GOSUniversity, Nespapers VOG\&S 12(4):555-562

Myrzagalieva AB (2006) A unique natural monument-the Sinegorskaya fir grove of the Kalbin ridge / News of the National Academy of Sciences of the Republic of Kazakhstan. 6:16-18

Nekratova NA, Nekratov NF (2005) Medicinal Plants of the Altai-Sayan Mountain Region. Resources, Ecology, Price Complexes, Population Biology, Rational Use Publishing House Tom. University, Tomsk, p 228

Niklfeld H, Schratt-Ehrendorfer L (1999) Rote Liste gefährdeter Farn- und Blütenpflanzen (Pteridophyta und Spermatophyta) Österreichs. 2. Fassung H. Niklfeld (Ed.), Rote Listen gefährdeter Pflanzen Österreichs. 2. Auflage. Grüne Reihe des Bundesministeriums für Umwelt, Jugend und Familie, Band 10. austria medien service, Graz

Olfelt JP, Freyman WA (2014) Relationships of North American members of Rhodiola (Crassulaceae). Botany 92(12), pp 1-10. https://doi.org/10.1139/ cjb-2014-0009

Olsson EM, von Scheele B, Panossian AG (2009) A randomised, double-blind, placebo-controlled, parallel-group study of the standardised extract SHR-5 of the roots of Rhodiola rosea in the treatment of subjects with stress-related fatigue. Planta Med 75(2):105-112. https://doi.org/10. 1055/s-0028-1088346

Panossian A, Wikman G, Sarris J (2010) Rosenroot (Rhodiola rosea): traditional use, chemical composition, pharmacology and clinical efficacy. Phytomedicine 17(7):481-493. https://doi.org/10.1016/j.phymed.2010.02.002 
Perrino EV, Musarella CM, Magazzini P (2021) Management of grazing Italian river buffalo to preserve habitats defined by Directive 92/43/EEC in a protected wetland area on the Mediterranean coast: Palude Frattarolo, Apulia, Italy. Euro-Mediterranean Journal for Environmental Integration 6(32):1-18. https://doi.org/10.1007/s41207-020-00235-2

Perrino EV, Wagensommer RP (2021) Crop Wild Relatives (CWR) Priority in Italy: Distribution, Ecology, In Situ and Ex Situ Conservation and Expected Actions. Sustainability 13(4):1682. https://doi.org/10.3390/su13041682

Peschel W, Kump A, Zomborszki ZP, Pfosser M, Kainz W, Horvath A, Csupor D (2018) Phenylpropenoid content in high-altitude cultivated Rhodiola rosea L. provenances according to plant part, harvest season and age. Ind Crop Prod 111:446-456

Peshkova GA (1994) Rhodiola genus - Rhodiola. Siberia flora; Novosibirsk, vol 7, pp 153-158

Platikanov S, Evstatieva L (2008) Introduction of wild golden root (Rhodiola rosea L.) as a potential economic crop in Bulgaria. Econ Bot 62(4):621627. https://doi.org/10.1007/s12231-008-9051-6

POWO (2021) Plants of the World Online. Facilitated by the Royal Botanic Gardens, Kew. http://www.plantsoftheworldonline.org/. Accessed 10 Feb 2021

Qin H, Zhao L (2017) Evaluating the threat status of higher plants in China Biodivers. Sci 25(7):689-695. https://doi.org/10.17520/biods.2017146

Rabotnov TA (1964) Determination of the age composition of species populations in a community // Field geobotany. Publishing House of the Academy of Sciences of the USSR, M-L., pp 132-145

Raunkiaer C (1934) The Life Forms of Plants and Statistical Plant Geography. Oxford University Press, London

Red Data Book of Kazakhstan (2014) Part 1. Plants. Under the editorship of Baitullina I.O. "AptPrintXXI" LLP, 2. p 452

Revushkin AS (1988) Highland flora of Altai. Tomsk University Press, p 320

Serebryakov IG (1962) Ecological morphology of plants. Life forms of angiosperms and conifers. M.: High school, p 380

Seregin AP (2020) Moscow Digital Herbarium: a consortium since 2019. https://doi.org/10.13140/RG.2.2.17337.93283. Moscow State University

Shadrin D, Valuyskikh O, Kanev VA (2020) A checklist of the bloomingg plants of komi republic (northeast of european russia) and their representation in bold and genbank databases. Acta Biologica Sibirica 6:357-367. https://doi.org/10.3897/abs.6.e54572

Smirnova OV (1976) The volume of the counting unit in the study of coenopopulations of plants of various biomorphs // Plant pricing: Basic concepts and structure. $M, p p$ 72-80

Sofronov RR, Egorova AA, Chichiginarova YuV (2016) The Current State of Population of Rhodiola rosea L. on the Ridges Sette-Daban and SuntarKhayata (North-East Yakutia). Science and education 3
Soni K, Rawat S, Gupta A, Yangzom K, Pandit S, Naik PK, Singh H (2010) Genetic characterisation of Rhodiola rosea using gene specific SSR and caps molecular markers. GEBJ-11. Genetic Engineering and Biotechnology Journal

Tasheva K, Kosturkova G (2012) The role of biotechnology for conservation and biologically active substances production of Rhodiola rosea: Endangered Medicinal Species. Sci World J. https://doi.org/10.1100/2012/274942.

Trutnev YuP, Compiled others, Camelyn RV et al (2008) Red Data Book of the Russian Federation (plants and mushrooms). Ministry of Natural Resources of the Russian Federation; Rosprirodnadzor; RBO; Moscow State University named after M.V. Lomonosov, p 855. (Ust - Kamenogorsk). Alpha press, 178

Uranov AA (1969) Vital state of a species in a plant community /. Bull MOIP Department of Biology 1:141-149

Urgamal M (2018) Species Catalogue of Rare and Threatened Vascular Plants of Mongolia. Bembi San Press, Ulaanbaatar, Mongolia

Valuiskih OE, Dubrovski YuA, Kuliugina EE, Kanev VA (2017) Rare plants of Halmersale mountain vicinities (Northern Urals): eco-phytocoenotic preferences, population structure and protection. Tomsk State Univ J Biol 40:66-87. https://doi.org/10.17223/19988591/40/4

Vasilyeva AN (1961) In: Pavlov NV (ed) Flora of Kazakhstan, vol 4. KASSR Publishing House, Alma-ata, p 353

Vedernikova OP, Nikandrova LM (2000) Ontogenetic atlas of medicinal plants. Yoshkar-Ola, pp 138-143

Yakubov VV (2019) To the taxonomy of Rhodiola L. (Crassulaceae DC.) of the Russian Far East. Botanical problems of the Southern Siberia and Mongolia 1(18):192-195. https://doi.org/10.14258/pbssm.2019039

Yaneva I, Balabanski V, Karanesheva T, Ignatov I (2020) Some endangered healings plants in Bulgaria - legislative regulation, protection, characteristic description, application, agricultural cultivation. Bulgarian J Agric Sci 26:847-852

Yegorina AV, Zinchenko YuK, Zinchenko ES (2003) Physical geography of the eastern Kazakhstan, p 182

Zibzeyev EG, Nedovesova TA (2015) Alpine vegetation of the Ivanovskiy, Prokhodnoy and Rossypnoy Ridges (Western Altai). Veg Russia. 27:96-124

\section{Publisher's Note}

Springer Nature remains neutral with regard to jurisdictional claims in published maps and institutional affiliations.

\section{Submit your manuscript to a SpringerOpen ${ }^{\circ}$ journal and benefit from:}

- Convenient online submission

- Rigorous peer review

- Open access: articles freely available online

- High visibility within the field

- Retaining the copyright to your article

Submit your next manuscript at springeropen.com 